\title{
A new species of Gulo from the Early Pliocene Gray Fossil Site (Eastern United States); rethinking the evolution of wolverines
}

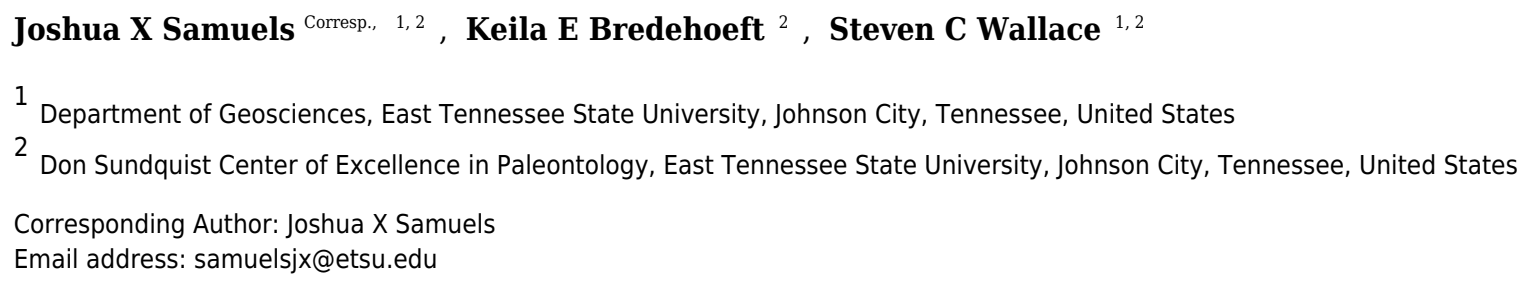

The wolverine (Gulo gulo) is the largest living member of the Mustelidae; a versatile predator formerly distributed throughout boreal regions of North America and Eurasia. Though commonly recovered from Pleistocene sites across their range, pre-Pleistocene records of the genus are exceedingly rare. Here, we describe a new species of Gulo from the Gray Fossil Site in Tennessee. Based on biostratigraphy, a revised estimate of the age of the Gray Fossil Site is Early Pliocene, near the Hemphillian - Blancan transition, between 4.9 and 4.5 Ma. This represents the earliest known occurrence of a wolverine, more than 1 million years earlier than any other record. The new species of wolverine described here shares similarities with previously described species of Gulo, and with early fishers (Pekania). As the earliest records of both Gulo and Pekania are known from North America, this suggests the genus may have evolved in North America and dispersed to Eurasia later in the Pliocene. Both fauna and flora at the Gray Fossil Site are characteristic of warm/humid climates, which suggests wolverines may have become 'cold-adapted' relatively recently. Finally, detailed comparison indicates Plesiogulo, which has often been suggested to be ancestral to Gulo, is not likely closely related to gulonines, and instead may represent convergence on a similar niche. 
1 A new species of Gulo from the Early Pliocene Gray Fossil Site (Eastern United States);

2 rethinking the evolution of wolverines

3

4 Joshua X. Samuels ${ }^{12}$, Keila E. Bredehoeft ${ }^{2}$, Steven C. Wallace ${ }^{12}$

$5 \quad{ }^{1}$ Department of Geosciences, East Tennessee State University, Johnson City, Tennessee, U.S.A.

$6 \quad{ }^{2}$ Don Sundquist Center of Excellence in Paleontology, East Tennessee State University, Johnson

7 City, Tennessee, U.S.A.

8

9

10

11

12

13

14

15

16

17

18

19

20

21

22 Corresponding author: Joshua X. Samuels

23 Email address: samuelsjx@etsu.edu 


\section{ABSTRACT}

25

The wolverine (Gulo gulo) is the largest living member of the Mustelidae; a versatile predator formerly distributed throughout boreal regions of North America and Eurasia. Though commonly recovered from Pleistocene sites across their range, pre-Pleistocene records of the genus are exceedingly rare. Here, we describe a new species of Gulo from the Gray Fossil Site in Tennessee. Based on biostratigraphy, a revised estimate of the age of the Gray Fossil Site is Early Pliocene, near the Hemphillian - Blancan transition, between 4.9 and 4.5 Ma. This represents the earliest known occurrence of a wolverine, more than 1 million years earlier than any other record. The new species of wolverine described here shares similarities with previously described species of Gulo, and with early fishers (Pekania). As the earliest records of both Gulo and Pekania are known from North America, this suggests the genus may have evolved in North America and dispersed to Eurasia later in the Pliocene. Both fauna and flora at the Gray Fossil Site are characteristic of warm/humid climates, which suggests wolverines may have become 'cold-adapted' relatively recently. Finally, detailed comparison indicates Plesiogulo, which has often been suggested to be ancestral to Gulo, is not likely closely related to gulonines, and instead may represent convergence on a similar niche.

\section{INTRODUCTION}

Wolverines (Gulo gulo) are the largest living terrestrial mustelid, have a circumboreal Holarctic historic distribution, and have commonly been considered a 'cold-adapted' species (Bonifay, 1971; Pasitschniak-Arts \& Larivière, 1995; Zigouris et al., 2013). Their diet is best characterized as being that of an opportunistic hypercarnivore, either ambushing and/or chasing prey or scavenging carcasses (Pasitschniak-Arts \& Larivière, 1995). Though primarily terrestrial, 
47 they are capable climbers, swimmers, and diggers (Pasitschniak-Arts \& Larivière, 1995; and 48 citations therein). Though wolverines are well-known, their fossil record is relatively sparse and 49 their origin has been controversial (ex. Kurtén, 1970; Harrison, 1981).

$50 \quad$ Fossil wolverines have been described from many Pleistocene and Holocene sites in 51 North America and Eurasia, including quite a few outside of the species' historic distribution 52 (Figure 1, Supplemental Table 1 and citations therein). Bryant (1987) compared a large sample 53 of Gulo from the Pleistocene of the Yukon to extant populations and to other Pleistocene records 54 of the genus from North America, which had been described as Gulo gidleyi (Hall, 1936) and 55 later referred to Gulo schlosseri (Kurtén \& Anderson, 1980). While Bryant (1987) found some small differences in average size, there was substantial overlap in size ranges and morphology between samples, leading him to conclude that all Quaternary Gulo should be treated as a single species. He did caution that a thorough study of Asian and European specimens was needed (Bryant, 1987), and several subsequent papers, largely focused on European material, have maintained G. schlosseri as a separate species (Pasitschniak-Arts \& Larivière, 1995; Kolfschoten, 2001; Krajcarz, 2012). Until a detailed analysis of specimens from all continents is undertaken, we will follow the taxonomy for Pleistocene wolverines from Eurasia in those studies. Specifically, following Bryant (1987), all Quaternary records of Gulo in North America 64 are considered G. gulo here. Kurtén, 1970; Hendey, 1978; Harrison, 1981; Alcalá, Montoya, \& Morales, 1994; PasitschniakArts \& Larivière, 1995; Montoya, Morales, \& Abella, 2011); mostly due to the sparse prePleistocene records. Only a single record of Gulo prior to the Quaternary has been reported; Gulo minor from the middle Pliocene age Udunga fauna from the Transbaikal region of Russia 
70 (Sotnikova, 1982; 1995; Erbajeva \& Alexeeva, 2013). G. minor is morphologically similar to,

71 but substantially smaller than $G$. gulo. It falls below the range of size variation reported for large

72 extant samples of G. gulo (Bryant, 1987; Anderson, 1998), as well as fossil samples from Europe

73 (Kormos, 1914; Bonifay, 1971; Kurtén, 1973; Döppes, 2001) and North America (Gidley \&

74 Gazin, 1938; Kurtén, 1973; Bryant, 1987; Anderson, 1998). Plesiogulo, known from Middle to

75 Late Miocene of Eurasia, Late Miocene and Early Pliocene of North America, and Late Miocene

76 to Early Pliocene of Africa, has often been discussed as a potential close relative of Gulo. While

77 some authors have considered Plesiogulo to be directly ancestral to Gulo (Viret, 1939; Kurtén,

78 1970; Pasitschniak-Arts \& Larivière, 1995), others considered such a line of descent to be

79 unlikely (Zdansky, 1924; Webb, 1969; Hendey, 1978; Harrison, 1981; Xu \& Wei, 1987; Alcalá,

80 Montoya, \& Morales, 1994; Montoya, Morales, \& Abella, 2011). Alternatively, some authors

81 have suggested independent origins of Gulo and Plesiogulo, with Gulo originating from a fisher

82 or marten-like ancestor in the late Miocene (Samuels \& Cavin, 2013) and Plesiogulo from an

83 early Miocene ischyrictine like Iberictis (Ginsburg \& Morales, 1992; Alcalá, Montoya, \&

84 Morales, 1994; Montoya, Morales, \& Abella, 2011).

85 Molecular data from a wide range of studies indicate Gulo is part of a clade (Guloninae)

86 that includes fishers (Pekania), martens (Martes), and the tayra (Eira). Among gulonines,

87 wolverines have been consistently found to be most closely related to martens, which form a

88 sister group to the fisher (Koepfli et al., 2008; Wolsan \& Sato, 2010; Sato et al., 2012; Li et al.,

89 2014; Malyarchuk, Derenko, \& Denisova, 2015; Zhu et al., 2016). Koepfli et al. (2008)

90 estimated the Guloninae diverged from other mustelids around $11.0 \mathrm{Ma}(95 \%$ confidence

91 interval [CI]: 9.4-12.5 Ma); whereas Sato et al. (2012) estimated $12.65 \mathrm{Ma}$ (95\% CI: $10.83-$

92 14.72 Ma). Li et al. (2014) examined the complete mitochondrial genomes of gulonines and 
93 estimated the Gulo-Martes clade diverged from Pekania between 8.9 and 7.05 Ma, most likely

94 around 7.6 Ma, while the divergence of Gulo and Martes was between 7.6 and 5.3 Ma, most

95 likely around 6.4-6.3 Ma. Similarly, Malyarchuk, Derenko, \& Denisova (2015) estimated the

96 divergence of Gulo and Martes to be around 5.6 Ma (95\% CI: 6.3-4.9 Ma). These estimates

97 coincide with the earliest records of definite gulonine mustelids in the late Miocene, namely

98 Pekania occulta from North America and P. palaeosinensis from Asia (Wang, Tseng, \&

99 Takeuchi, 2012; Samuels \& Cavin, 2013), and Martes ginsburgi and M. wenzensis from Europe

100 (Stach, 1959; Wolsan, 1989a; Anderson, 1994; Sato et al., 2003; Montoya, Morales, \& Abella,

101 2011). Each of these molecular estimates for the divergence of Gulo from other closely related

102 gulonines (Martes and Pekania) are long after the earliest records of Plesiogulo, which date to

103 the middle Miocene (MN6) of Turkey and Kazakhstan, between 15.2 and 12.5 Ma (Schmidt-

104 Kittler, 1976; Montoya, Morales, \& Abella, 2011). Though it seems clear that Plesiogulo falls

105 along a different lineage, new and/or older records could clarify the origin of Gulo.

106 Here, we describe a new species of Gulo from the Early Pliocene age Gray Fossil Site of

107 Tennessee (Figure 1). The specimen described here represents the earliest record of Gulo and

108 predates other records of the genus by over 1 million years. Similarity of this new species to

109 early fishers (Pekania), suggests that wolverines may have originated in North America. In light

110 of this discovery and other fossil records of Gulo, we also discuss the historical biogeography

111 and ecology of wolverines, as well as their commonly accepted 'cold-adapted' nature.

\section{MATERIALS AND METHODS}

114 The electronic version of this article in Portable Document Format (PDF) will represent a 115 published work according to the International Commission on Zoological Nomenclature (ICZN), 
116 and hence the new names contained in the electronic version are effectively published under that

117 Code from the electronic edition alone. This published work and the nomenclatural acts it

118 contains have been registered in ZooBank, the online registration system for the ICZN. The

119 ZooBank LSIDs (Life Science Identifiers) can be resolved and the associated information viewed

120 through any standard web browser by appending the LSID to the prefix http://zoobank.org/. The

121 LSID for this publication is: [29DF929D-D054-4912-A2B1-FFEEFD4BDE1B]. The online

122 version of this work is archived and available from the following digital repositories: PeerJ,

123 PubMed Central and CLOCKSS.

124 Dental nomenclature follows Ginsburg (1999). Measurements of the teeth, to the nearest

$1250.01 \mathrm{~mm}$, were made using Mitutoyo Absolute digital calipers. Measurements include

126 anteroposterior length and transverse breadth of the teeth. For the P4, maximum transverse

127 breadth was measured at both the protocone $\left(\mathrm{P} 4 \mathrm{~W}_{\mathrm{pro}}\right)$ and the metastyle $\left(\mathrm{P} 4 \mathrm{~W}_{\mathrm{met}}\right)$, and for the

$128 \mathrm{M} 1$ lengths were measured for both inner $\left(\mathrm{M} \mathrm{L}_{\text {int }}\right)$ and outer lobes $\left(\mathrm{M}_{1} \mathrm{~L}_{\text {ext }}\right)$.

129 Measurements were taken, and comparisons were made, with specimens of extant and

130 extinct mustelids from several collections. Extant samples included Gulo gulo (n=36), Pekania

131 pennanti $(\mathrm{n}=22)$, Martes americana $(\mathrm{n}=11)$, Martes flavigula $(\mathrm{n}=1)$, Martes foina $(\mathrm{n}=1)$, Martes

132 martes $(\mathrm{n}=1)$, Eira barbara $(\mathrm{n}=5)$; this includes all extant gulonine species other than Martes

133 melampus and Martes zibellina. Fossil samples included Pleistocene and Holocene specimens of

134 Gulo and Pekania from North America, late Miocene specimens of Pekania occulta and

135 Plesiogulo marshalli from North America, as well as casts of Pekania palaeosinensis from Asia

136 and Plesiogulo from North America. All material was also compared to specimens and

137 measurements in a wide range of publications (including Zdansky, 1924; Gidley \& Gazin, 1933;

138 Gidley \& Gazin, 1938; Teilhard de Chardin \& Leroy, 1945; Stach, 1959; Anderson, 1970; 1998; 
139 Kurtén, 1970; 1973; Hendey, 1978; Harrison, 1981; Bryant, 1987; Wolsan, 1989; Ginsburg \&

140 Morales, 1992; Döppes, 2001; Haile-Selassie, Hlusko, \& Howell, 2004; Montoya, Morales, \&

141 Abella, 2011; Peigné, 2012; Wang, Tseng, \& Takeuchi, 2012). Complete measurement data for

142 all mustelids studied are included in Supplemental Table 2.

143 Fossil and modern specimens used for comparative illustrations were photographed with

144 the alveolar margin of the upper carnassial (P4) parallel to the photographic plane. This is

145 important to note, as most published fossil mustelids have been photographed with the palate

146 parallel to the photographic plane (Supplemental Figure 1A); in that orientation the alveolar

147 margins of the cheek teeth are at a slightly oblique angle, with the lateral portions slightly ventral

148 to the medial. A consequence of this difference in photography and illustration methodology is

149 that some of the lingual portions of the tooth, like the P4 lingual cingulum, are not obscured

150 using our methodology (Supplemental Figure 1B).

151 Specimen Repositories-ETMNH, East Tennessee State University Museum of Natural History

152 - Fossil Collection, Gray, Tennessee; ETVP, East Tennessee State University Museum of

153 Natural History - Comparative Collection, Johnson City, Tennessee; LACM, Natural History

154 Museum of Los Angeles County, Los Angeles, California; MVZ, Museum of Vertebrate

155 Zoology, University of California, Berkeley, California; UCLA, Donald R. Dickey Collection of

156 the University of California, Los Angeles, Los Angeles, California; USNM, United States

157 National Museum of Natural History (Smithsonian Institution), Washington, D.C.

159 GEOLOGICAL SETTING

160 The Gray Fossil Site in northeastern Tennessee includes deposits that represent an ancient

161 sinkhole containing a small, but deep lake, which gradually filled with sediment (Shunk, Driese, 
162 \& Clark, 2006; Shunk, Driese, \& Dunbar, 2009). Sediment cores have revealed a series of

163 rhythmites in the upper lacustrine strata, which alternate between fine-grained silty clay layers

164 and coarse-grained, organic rich layers (Shunk, Driese, \& Clark, 2006; Shunk, Driese, \& Dunbar,

165 2009). Shunk, Driese, \& Dunbar (2009) estimated the sinkhole lake filled with sediment in

166 approximately 4,500 to 11,000 years. Within the sedimentary layers are well-preserved and

167 diverse flora and fauna (ex. Parmalee et al., 2002; Wallace \& Wang, 2004; Mead et al., 2012;

168 Zobaa et al., 2011; Ochoa et al., 2012; 2016; Worobiec, Liu, \& Zavada, 2013), which indicate a

169 forested environment was present. Macro- and microfossils indicate the presence of a forest

170 dominated by oak (Quercus), hickory (Carya), and pine (Pinus), as well as a variety of

171 herbaceous taxa (Ochoa et al., 2016; and references therein). Isotopic analyses of carbon and

172 oxygen from teeth of ungulates at the site indicate a relatively dense forest, with some more open

173 grass-dominated habitats nearby, and climate with little seasonal temperature and precipitation

174 variation (DeSantis \& Wallace, 2008). Ochoa et al. (2016) interpreted the flora at the Gray Fossil

175 Site as indicative of a woodland or woodland savanna environment characterized by frequent

176 disturbance. The occurrence of bald cypress (Taxodium) and tupelo (Nyssa) leaves and pollen at

177 Gray (Brandon, 2013; Worobiec, Liu, \& Zavada, 2013) suggest the presence of humid riparian or

178 wetland areas. Fauna includes many taxa indicative of aquatic environments, such as fish,

179 neotenic salamanders, aquatic turtles, Alligator, and beavers (Parmalee et al., 2002; Boardman \&

180 Schubert, 2011; Mead et al., 2012; Jasinski, 2013; Bourque \& Schubert, 2015).

181 Age of the Gray Fossil Site has been previously reported as constrained between 7 and

$1824.5 \mathrm{Ma}$, based on the stratigraphic ranges of the rhino Teleoceras and ursid Plionarctos (Wallace

183 \& Wang, 2004). Teleoceras has commonly been considered an index taxon for the Hemphillian

184 NALMA, but it is worth noting that there are several Pliocene records of Teleoceras, including 
185 Blancan age specimens from White Bluffs in Washington (Gustafson, 2012), Beck Ranch in

186 Texas (Madden \& Dahlquest, 1990), and Saw Rock Canyon in Kansas (Prothero \& Manning,

187 1987). It is important to note that the record from Beck Ranch in Texas has been interpreted as a

188 tooth reworked from older sediments (Prothero, 2005) and the report from Kansas does not refer

189 to any cataloged specimens, but the presence of Ogmodontomys sawrockensis indicates Saw

190 Rock Canyon is Blancan in age (Martin \& Peláez-Campomanes, 2014; Martin, Peláez-

191 Campomanes, \& Viriot, 2017). Some of the latest rhino records in North America may be

192 younger than 4.5 Ma and potentially as young as 3.5 Ma (Gustafson, 2012). Gustafson (2012)

193 asserted that such records indicate that the presence of Teleoceras at a site is insufficient

194 justification for assigning a Hemphillian age to the fauna, as has been done for a variety of

195 eastern U.S. localities, specifically the Palmetto fauna (Webb et al., 2008) and Pipe Creek

196 Sinkhole (Farlow et al., 2001; though see Martin, Goodwin, \& Farlow, 2002; Martin, 2010 for a

197 revised age of that site).

198 A number of recently identified taxa from the Gray Fossil Site have good fossil records

199 and limited stratigraphic ranges. Based on first and last appearance data (FAD, LAD) of these

200 taxa derived from the MIOMAP/FAUNMAP Databases (Carrasco et al., 2007; Graham \&

201 Lundelius, 2010; http://www.ucmp.berkeley.edu/neomap/), NOW Database (Fortelius, 2013;

$202 \mathrm{http}: / /$ pantodon.science.helsinki.fi/now/), and recent publications, we can produce a revised

203 estimate of the age of the Gray Fossil Site. The cricetids Neotoma and Symmetrodontomys have

204 their first appearances near the Hemphillian - Blancan transition, approximately 4.9 or $4.8 \mathrm{Ma}$

205 (Martin, 2000; Martin, Goodwin, \& Farlow, 2002; Bell et al., 2004; Lindsay, 2008; Martin,

206 Peláez-Campomanes, \& Viriot, 2017). The leporid Notolagus lepusculus and the mephitid

207 Buisnictis breviramus appeared in, and are restricted to, the early Blancan (FAD 4.9 Ma). 
208 Among other taxa at the site are the cricetid Repomys (FAD 6.6 Ma) and the leporid Alilepus 209 vagus (FAD 5.9), which appeared in the Hemphillian and survived into the Blancan. The

210 dromomerycid Pediomeryx appeared earlier in the Miocene, but disappeared near the

211 Hemphillian - Blancan transition (LAD 4.7 Ma) (Voorhies, 1990; Janis and Manning, 1998).

212 However, a recently described record of Pediomeryx from the Lee Creek Mine Local Fauna in

213 North Carolina (Eshelman \& Whitmore, 2008) is early Blancan in age, as Marx and Fordyce

214 (2015) bracket the age of the lower Yorktown Formation (including Lee Creek Mine) between

2154.9 and 3.9 Ma.

216 In sum, none of the mammal genera at the Gray Fossil Site are restricted to the late

217 Miocene or Hemphillian NALMA, and some taxa are actually characteristic of early Blancan

218 (Early Pliocene) faunas. For example, the Gray Fossil Site and the early Blancan age Beck

219 Ranch fauna in Texas (Dahlquest, 1978) share the following (Teleoceras, Neotoma,

220 Symmetrodontomys, Notolagus lepusculus, Buisnictis breviramus). Other than Neotoma, none of

221 these taxa survived later than the early Blancan ( 2.5 Ma; Bell et al., 2004). Considering the

222 Gray Fossil Site fauna in total, a revised estimate of the age of the Gray Fossil Site is Early

223 Pliocene near the Hemphillian - Blancan transition, likely between 4.9 and 4.5 Ma (Figure 2).

224

225 RESULTS

226 Systematic Paleontology

227

228

229

230

231

232
Class MAMMALIA Linnaeus, 1758

Order CARNIVORA Bowdich, 1821

Family MUSTELIDAE Fischer, 1817

Subfamily GULONINAE Gray, 1825

Genus Gulo Pallas, 1780

Type Species-Gulo gulo. 
233 Included Species-Gulo minor, Gulo schlosseri, Gulo sudorus (new species).

234 Distribution - Early Pliocene of Tennessee, middle Pliocene of Russia, Pleistocene to recent of

235 North America and Eurasia (see Supplemental Table 1 for a listing of fossil sites).

236

237

238

239

240

241

242

243

244

245

246

247

248

249

250

251

252

253

254

255

256
Gulo sudorus New Species

(Figure 3, Table 1)

Holotype-ETMNH 3663, partial right maxilla with P2 and P4.

Locality - Gray Fossil Site, Washington County, Tennessee.

Age-Early Pliocene (earliest Blancan).

Diagnosis - P2 broad and robust, and P4 enlarged with a broad paracone and metastyle; these features are typical of Gulo, but not observed in any other gulonines. P4 protocone anteriorly positioned and infraorbital foramen is oval, unlike Eira. P4 lacks an external median rootlet, unlike Pekania. P4 protocone and parastyle larger than in extant Gulo gulo and all other previously described species of Gulo. P4 parastyle includes a small, conical parastylar cusp. P4 metastyle tapers distally, unlike the posteriorly broad and squared metastyle of other Gulo species. P2 not as strongly reduced as in other members of the genus. Infraorbital foramen is located above the anterior root of the P4, rather than anterior to the P4 as is typical of other species of Gulo.

Etymology_ _Sudorus" from the Latin for "sweaty". In reference to the warm, humid climate present in the Early Pliocene of Tennessee relative to the typical boreal habitat that the modern taxon is known for inhabiting.

Description - The holotype specimen (ETMNH 3663) consists of a left maxilla fragment with the P2 and P4 (Figure 3). There is little of the maxilla preserved, though some anatomical information can be derived from the specimen. A portion of the infraorbital foramen is preserved above the anterior root of the $\mathrm{P} 4$ and its lateral margin suggests an oval shape; the foramen is 
257 approximately $10.8 \mathrm{~mm}$ in dorsoventral diameter. The $\mathrm{P} 2$ crown is intact and only a small

258 portion of the posterior surface of the $\mathrm{P} 4$ protocone is missing. The $\mathrm{P} 2$ shows minor, and $\mathrm{P} 4$

259 moderate, wear; indicating that this was an adult individual.

260 The P2 is double-rooted, robust, and distinctly larger than in other members of the genus

261 (Table 1). Though it is larger in absolute terms, the size of the P2 relative to the P4 in ETMNH

2623663 falls within the range of variation observed in extant Gulo gulo (P2L/P4L, Table 1). The P2

263 has a single principal cusp and a ridge running along its midline, most distinct posterior to the

264 principal cusp. There is a low, relatively indistinct cingulum on the $\mathrm{P} 2$, which is most prominent

265 along its posterior margin.

266 The P4 is robust and three-rooted, as is typical of the genus. Also typical of Gulo, there is

267 no external median rootlet present on the $\mathrm{P} 4$, which is a feature that has been used to characterize

268 Pekania (though see comparisons below). The tooth bears a distinct parastyle and a relatively

269 larger protocone than in other species of Gulo. The parastyle bears a small, round parastylar

270 cusp. A pair of low ridges run along the anterior surface of the paracone; the lateral ridge ends at

271 the posterobuccal edge of the parastylar cusp, the medial ridge forks in two and ends just

272 posterior to the parastyle. Like other gulonines, Gulo sudorus has a relatively deep inflection of

273 the anterior portion of the $\mathrm{P} 4$, between the parastyle and protocone. The protocone is particularly

274 large and extends anteromedially from the base of the paracone, projecting nearly as far

275 anteriorly as the parastyle. The metastyle of G. sudorus is mesially broad, tapers distally, and

276 bears a distinct lingual cingulum. There is a small cingulum along the base of the metastyle on

277 the lingual surface of the tooth and a subtle remnant of an anterior cingulum along the anterior

278 margin of the protocone, both of which are common in known gulonines. 
279 Comparisons - Overall, the morphology of ETMNH 3663 is similar to known fossil and

280 modern specimens of Gulo and other gulonine mustelids (Figure 4), but has a set of features that

281 distinguish it from other taxa. As in extant and Pleistocene specimens of Gulo, the infraorbital

282 foramen of ETMNH 3663 has an oval shape, but it is located more posteriorly, above the anterior

283 root of the $\mathrm{P} 4$, rather than above the $\mathrm{P} 3$ or anterior margin of the $\mathrm{P} 4$ as in G. gulo (Harrison

284 1981). Position and shape of the infraorbital foramen in extant and fossil Pekania and Martes are

285 variable, either oval or round and anterior to the $\mathrm{P} 4$ as in Gulo or above the anterior root of the

286 P4. In Eira the infraorbital foramen is round and located above the anterior root or middle of the

287 P4. In Plesiogulo the infraorbital foramen is relatively round in cross section and located above

288 the anterior root or middle of the P4 (Harrison 1981).

289 There is a deep inflection between the parastyle and protocone of the P4 in ETMNH 3663

290 and G. gulo, and in the latter that inflection is occupied by the posterior margin of the P3 (Figure

291 4A). In extant and fossil gulonines, a similar arrangement is also seen in individuals of Martes

292 flavigula, M. martes, and Pekania palaeosinensis, but not in Eira barbara, M. americana, $P$.

293 occulta, P. diluviana, or P. pennanti.

294 While a parastylar cusp is occasionally present in the P4 of Gulo gulo, it is never as

295 substantial as in ETMNH 3663. Similarly, the protocone is proportionately larger than in extant

296 Gulo and other fossils of the genus (Table 1). Presence of a large protocone and parastyle is

297 typical of other gulonine mustelids, like Pekania, Martes, and Eira; though the protocone is

298 more posteriorly positioned in Eira than other gulonines. A distally tapered P4 metastyle like

299 that of ETMNH 3663 is seen in Eira, Pekania, and Martes, but not in other species of Gulo.

300 Specifically, in both Gulo gulo and G. schlosseri the P4 metastyle is broad and squared distally,

301 and bears a distinct u-shaped or square extension at the posterior margin of the metastyle blade. 
302 That extension runs anteroposteriorly along the buccal margin of the metastyle, then transversely

303 to join the metastyle blade at a nearly right angle (Figure 4A).

304 Pekania occulta from the late Miocene of Oregon has a more robust P4 than other

305 Pekania and Martes species, as well as a particularly large P4 protocone and distally tapered

306 metastyle, and an oval-shaped infraorbital foramen located above the anterior root of the P4.

307 Each of those features are similar to ETMH 3663, though P. occulta is smaller and lacks the

308 robust anterior premolars seen in Gulo sudorus. Additionally, as is typical of the genus Pekania,

309 P. occulta bears an external median rootlet on the P4, which is not present in ETMNH 3663.

310 Due to the fragmentary material known for both taxa, the morphology of Gulo sudorus

311 and G. minor from the middle Pliocene of Asia cannot be directly compared. However, all

312 measurements of the lower dentition of G. minor (Sotnikova, 1982) fall outside the range of

313 variation of extant and fossil samples of Gulo, between 7 and $16 \%$ smaller than the smallest

314 extant wolverines studied. In contrast, all dimensions the upper dentition of G. sudorus, other

315 than length and width of the P2, fall within the ranges of G. gulo and G. schlosseri, and all are

316 larger than the means of extant samples (Table 1). As such, it is unlikely that known specimens

317 of G. sudorus and G. minor are from the same taxon.

318 A hypothesis of the evolutionary relationships of gulonine mustelids is presented in

319 Figure 5. Relationships of extant gulonine taxa are based on molecular phylogenetic studies

320 (Koepfli et al., 2008; Sato et al., 2012; and Li et al., 2014); estimated divergence times are based

321 on the protein coding region data set in Li et al. (2014), except the divergence time of Guloninae

322 from other "crown" mustelids (Helictidinae, Ictonychinae, Lutrinae, and Mustelinae) which is

323 based on the multidivtime analysis of Sato et al. (2012). Geologic ages of known gulonine fossils

324 are derived from the MIOMAP/FAUNMAP Databases (Carrasco et al., 2007; Graham \& 
325 Lundelius, 2010; http://www.ucmp.berkeley.edu/neomap/), NOW Database (Fortelius, 2013;

$326 \mathrm{http} / /$ pantodon.science.helsinki.fi/now/), and recent publications; the age of Gulo sudorus is

327 based on the biostratigraphic framework presented in Figure 2. Note that the placements of

328 extinct taxa in the phylogeny are not based on a cladistics analysis, but rather morphological

329 comparisons made here and in a number of earlier studies. The placement of the extinct Pekania

330 palaeosinensis, Eirictis, and Sminthosinis are based on Wang, Tseng, \& Takeuchi, 2012, and the

331 placement of M. wenzensis is based on Anderson, 1994 and Sato et al., 2003.

332 The basal placement of Gulo sudorus within the genus is based on the following features:

333 1) infraorbital foramen is positioned posteriorly in G. sudorus, as in Eira and some species of

334 Pekania and Martes, and in contrast to the anterior position of the foramen in G. schlosseri and

335 G. gulo; 2) P2 larger than in any studied specimens of G. schlosseri and G. gulo, which have

336 reduced anterior premolars; 3) P4 metastyle tapers posteriorly in G. sudorus, as in Ischyrictis

337 zibethoides, Eira, Pekania, and Martes, and in contrast to the broad and posteriorly squared

338 metastyle of G. schlosseri and G. gulo; 4) the $\mathrm{P} 4$ protocone and parastyle are particularly large in

339 G. sudorus, as in Ischyrictis zibethoides, Pekania, and Martes, and larger than in G. schlosseri

340 and G. gulo. Each of those features of G. sudorus are present in other gulonine genera and thus

341 may represent primitive features for the Guloninae. Gulo minor is considered derived relative to

342 G. sudorus, as the only differences it shows from G. schlosseri and G. gulo are the following

343 features (from Sotnikova, 1982; Kalmykov, 2015): 1) smaller body size; 2) weaker curvature of

344 the tooth row, with the $\mathrm{m} 1$ trigonid offset at an oblique angle to the $\mathrm{p} 3$ and $\mathrm{p} 4$, whereas the $\mathrm{p} 3$,

$345 \mathrm{p} 4$, and $\mathrm{m} 1$ trigonid are all aligned in G. schlosseri and G. gulo; 3) relatively elongate and

346 narrow p3 and p4 (length/width ratio of premolars higher than in any studied samples of other

347 members of the genus). Given the substantial variability in body size of extant wolverines, with 
348 the largest studied samples having dentition 25\% larger than the smallest (Table 1), the

349 somewhat smaller size of G. minor is not interpreted as a particularly substantial difference. The

350 difference in the curvature of the toothrow is also not particularly distinctive, as the dental arcade

351 of extant wolverines is highly variable in terms of rotation and alignment of the anterior

352 premolars (Jung et al., 2016). Within the genus Pekania, placement of P. occulta as the most

353 basal member is based on the following features: 1) robust $\mathrm{P} 4$, more robust than in other

354 members of the genus, 2) P4 protocone larger than in other members of the genus. Each of these

355 features are similar to Gulo, and thus may represent the primitive state for the Pekania - Gulo /

356 Martes clade.

358 DISCUSSION

359 Origin and evolution of Gulo

360 Origins of the subfamily Guloninae and the genus Gulo have long been uncertain, but

361 recently described fossils have substantially improved our understanding of the group's

362 evolution. The earliest species that has been referred to any extant gulonine genus is "Martes"

363 laevidens from the early Miocene (MN 3) of Germany (Dehm, 1950). However, Sato et al.

364 (2003) noted the basicranial anatomy of "M." laevidens indicated it was not a member of the

365 extant genus Martes; the incompletely ossified suprameatal fossa (Wolsan, 1993) is a

366 plesiomorphic trait among mustelids (Hughes, 2012). There are many other described examples

367 of potential early "Martes" species from the early and middle Miocene of Eurasia, North

368 America, and North Africa (Anderson, 1994; Baskin, 1998; Ginsburg, 1999; Hughes, 2012);

369 however; most are not closely related to extant gulonine genera, but instead represent stem

370 groups outside of the crown clade Guloninae (Anderson, 1994; Sato et al., 2003; Wang, Tseng, 
371 \& Takeuchi, 2012; Li et al., 2014). Moreover, some of these "Martes" taxa show similarity to

372 ischyrictines (Ginsburg \& Morales, 1992; Montoya, Morales, \& Abella, 2011) and, in some

373 cases, have been referred to the ischyrictine genera Hoplictis, Plionictis, and Sthenictis

374 (Anderson, 1994; Baskin, 1998; Hughes, 2012).

375 Similarities of many of these potential early "Martes" species with members of the

376 Guloninae is likely due to the retention of plesiomorphic traits in extant gulonine taxa, or more

377 likely ecomorphological convergence with the genus Martes. Complicating the issue, extant

378 gulonines, including species of Martes and Gulo, are characterized by highly polymorphic

379 dentition (Wolsan, Ruprecht, \& Buchalczyk, 1985; Wolsan, 1988; 1989b; Döppes, 2001; Jung et

380 al., 2016), and it seems likely that ancestral forms shared the same level of variation. Given the

381 polymorphism observed in extant taxa and incomplete fossil material known for many early and

382 middle Miocene species, early taxa referred to "Martes" are in need of detailed study, which may

383 reveal how they are (or are not) related to gulonines.

384 Something similar to Ischyrictis zibethoides, which is known from the Early and Middle

385 Miocene (MN 5-8) of Europe (Peigné, 2012), could be ancestral to gulonines. I. zibethoides

386 exhibits a dentition which has some similarity to that of gulonines; the P4 protocone and

387 parastyle are large, and there is a deep inflection in the anterior margin of the tooth. The M1 has

388 a distinctive round lingual margin. Lastly, the age of that taxon is similar to the estimated

389 divergence of gulonines from other mustelids, which molecular estimates placed near 11.0 Ma

390 (Koepfli et al., 2008) or 12.65 Ma (Sato et al., 2012).

391 The oldest confirmed gulonines are early records of fishers, including Pekania occulta

392 from North America (Samuels \& Cavin, 2013) and P. palaeosinensis from Asia (Wang, Tseng,

393 \& Takeuchi, 2012). Pekania, which was formerly considered a subgenus of Martes, is 
394 distinguished by the presence of an external median rootlet on the upper P4 (Anderson, 1994;

395 Samuels \& Cavin, 2013). Morphology of $P$. occulta, particularly the robust P4 with a large

396 protocone, is similar to extant Gulo gulo and G. sudorus, suggesting that species may be similar

397 to the shared ancestor of more recent Pekania and Gulo. The late Miocene ages of P. occulta

398 (Hemphillian NALMA, 7.3 - 7.05 Ma) and P. palaeosinensis (Baodean ALMA) are consistent

399 with molecular estimates for divergence of Pekania from the Martes / Gulo clade (Koepfli et al.,

400 2008; Sato et al., 2012; Li et al., 2014).

401 Interestingly, one studied specimen of recent Gulo gulo (ETVP 269) possesses an

402 external median rootlet on both upper carnassials (Figure 6). Presence of an external median

403 rootlet on the upper P4 is considered diagnostic of the genus Pekania (Anderson, 1970). Though

404 it is only observed in a single specimen, this apparent atavistic trait lends support to both

405 molecular and fossil evidence indicating a close relationship between Pekania and Gulo. If Gulo

406 evolved from a fisher-like ancestor, as we hypothesize, the occurrence of an external median

407 rootlet in ETVP 269 is not as surprising as it would be if the two taxa were not so closely related.

408 An early representative of the genus Martes may be M. ginsburgi (Montoya, Morales, \&

409 Abella, 2011) from the late Miocene of Spain (MN 13), which is similar to both M. anderssoni

410 (Schlosser, 1924) from latest Miocene/Early Pliocene and M. zdanskyi (Teilhard de Chardin \&

411 Leroy, 1945) from the late Pliocene of China. M. ginsburgi lacks an external median rootlet on

412 the P4 and the $\mathrm{m} 1$ morphology is distinct from Pekania (Montoya, Morales, \& Abella, 2011). M.

413 ginsburgi is also very similar to M. martes, suggesting that it may be similar to the ancestor of

414 extant martens (Montoya, Morales, \& Abella, 2011). Detailed study of M. ginsburgi, $M$.

415 anderssoni, and other late Miocene species referred to the genus should help resolve how these

416 taxa are related to extant martens. 
418 Martes wenzensis (Stach, 1959) from the Pliocene (MN 15) of Poland (Wolsan, 1989a) to be the

419 earliest undoubted member of the genus Martes. M. wenzensis is known from multiple skulls and

420 characterized by having longer and more robust carnassials than extant Martes (Stach, 1959).

421 Measurements of M. wenzensis fall within the size range of extant and fossil samples of Pekania

422 (Table 1), but it clearly lacks the external median rootlet of the P4 in that taxon. Ages of both 423 species, about 7.1 - 5.3 Ma for M. ginsburgi and 4.0 - 3.3 Ma for M. wenzensis, are consistent

424 with molecular divergence estimates of the Martes / Gulo clade from other gulonines (Koepfli et 425 al., 2008; Sato et al., 2012; Li et al., 2014); comparable in age to G. sudorus and slightly younger 426 than the earliest records of Pekania.

There are a number of distinct evolutionary trends that can be recognized by examination 428 of the teeth of gulonines. Compared to other extant gulonine mustelids, Gulo has strongly reduced anterior premolars (Table 1, Figure 4). Both Bryant (1987) and Jung et al. (2016) have suggested there is a general evolutionary trend in loss/reduction/rotation of the anterior

431 premolars and enlargement of the carnassials in Gulo, which is a consequence of the

432 hypercarnivorous diet of wolverines. Since the canines and carnassials are the primary teeth used 433 to kill and process prey, and reduction in snout length increases the bite force of those teeth, it is 434 not surprising that the anterior premolars of Gulo are frequently missing or rotated (Jung et al., 435 2016). The $\mathrm{P} 2$ of G. sudorus is larger than all previously described members of the genus (Table 436 1). In terms of relative size ( $\mathrm{P} 2 \mathrm{~L} / \mathrm{P} 4 \mathrm{~L})$, G. sudorus has anterior premolars intermediate in size 437 between the means of G. gulo and related taxa like Pekania and Eira. The premolar morphology 438 of G. sudorus suggests that the evolutionary trend of premolar reduction in the genus Gulo had 439 already begun in the Early Pliocene. 
441 other gulonine mustelids (P4L/M1L $\left.{ }_{\text {int }}\right)$ (Table 1, Figure 4; Tseng et al., 2009). The P4 length is

442 well over twice as long as the maximum length of the M1 (inner lobe) in all Gulo studied; the

443 only other taxa that approach similar proportions are some specimens of Eira and the tayra-like

444 Sminthosinis bowleri from the Pliocene (early Blancan) of Idaho (Bjork, 1970). Similarly, the

445 ratio of $\mathrm{P} 4$ length to the transverse width of the M1 was greater than 1.5 in nearly all Gulo

446 studied, whereas it was less than 1.25 in all other taxa. As in the premolars, the relative size of

447 the M1 and m1 talonid in Gulo likely reflect adaptations for hypercarnivory; reduction of the

448 post-carnassial dentition and shortening the rostrum increase mechanical advantage when biting

449 with both the canines and carnassials.

450

451 Plesiogulo and convergent evolution of wolverine-like mustelids

452 Plesiogulo, known from many mid to late Miocene and Pliocene sites in North America, 453 Eurasia, and Africa, has long been discussed as a potential relative of Gulo (Zdansky, 1924;

454 Viret, 1939; Webb, 1969; Kurtén, 1970; Hendey, 1978; Harrison, 1981; Xu \& Wei, 1987;

455 Alcalá, Montoya, \& Morales, 1994; Pasitschniak-Arts \& Larivière, 1995; Montoya, Morales, \&

456 Abella, 2011). Careful consideration of the morphology of extant gulonine mustelids (Figure 4)

457 and recently discovered fossil material suggests that similarity between Gulo and Plesiogulo is

458 likely a result of convergence on a similar niche, rather than the result of a close relationship.

459 Eira, Pekania, Martes, and Gulo all have a distinct P4 parastyle (though it is variably well-

460 developed), but only a distinct anterior cingulum or occasionally a weak parastyle are seen in

461 Plesiogulo (contrary to indication that the parastyle is absent; Harrison, 1981). The inner lobe of

462 the M1 is expanded posterolingually in Plesiogulo to form a broad talon, but not in Gulo. 
463 Similarly, the $\mathrm{m} 1$ talonid is proportionately much longer and wider in Plesiogulo than Gulo, and

464 has a shallow basin (Stehlin, 1931; Teilhard de Chardin \& Leroy, 1945; Kurtén, 1970). A

465 number of evolutionary reversals (P4 parastyle reappearance, M1 reduction, M1 talon reduction,

$466 \mathrm{~m} 1$ talonid reduction) would be required for Gulo to have been derived from something like

467 Plesiogulo, as has been previously noted (Zdansky, 1924; Webb, 1969; Harrison, 1981; Xu \&

468 Wei, 1987). On the other hand, few changes, other than increased size and robustness of the

469 carnassial and premolars, are necessary for derivation of Gulo from something similar to early

470 species of Pekania (P. occulta, P. palaeosinensis).

471 Rather than showing similarity to gulonine mustelids, Plesiogulo is most similar to the

472 ischyrictine Iberictis, which is known from the early Miocene (MN4) of Spain and France

473 (Ginsburg \& Morales, 1992). Both Plesiogulo and Iberictis display robust anterior premolars

474 with strong cingula, a P4 with a large protocone and relatively broad metastyle, large M1 with a

475 posterolingually expanded inner lobe, and relatively broad and elongate $\mathrm{m} 1$ talonid. In contrast,

476 Gulo and Pekania have a relatively narrow P4 metastyle and M1 with inner lobe only slightly

477 longer than the outer lobe, and Gulo also has a distinctly reduced M1 and $\mathrm{m} 1$ talonid. In Iberictis

478 and most species of Plesiogulo, the $\mathrm{m} 1$ has a distinct metaconid that is approximately equal in

479 height to the paraconid, while the $\mathrm{m} 1$ of Gulo has no distinct metaconid. As in Gulo, the $\mathrm{m} 1$

480 metaconid is absent in Plesiogulo praecocidens from the late Miocene of Asia and variably

481 absent in the Pliocene P. monspessulanus (Viret, 1939; Kurtén, 1970; Bonifay, 1971; Hendey,

482 1978; Alcalá, Montoya, \& Morales, 1994; Koufos, 2000). Additionally, P. monspessulanus has a

483 single-rooted p2, while the p2 is double-rooted in Gulo, further suggesting the two are not

484 closely related (Hendey, 1978). 
Another feature distinguishing Gulo from Plesiogulo are the proportions of the teeth

486 (Table 1, Figure 4). Plesiogulo and Gulo both have robust premolars, wide relative to their

487 length, but the anterior premolars are smaller in proportion to the carnassial (P2L/P4L) in all 488 samples of Gulo. Similarly, the relative size of the $\mathrm{M} 1\left(\mathrm{P} 4 \mathrm{~L} / \mathrm{M}_{1} \mathrm{~L}_{\text {int }}\right)$ in all samples of Gulo is 489 relatively smaller than those of described and examined specimens of Plesiogulo. Additionally, no reported specimens of Plesiogulo display the premolar rotation commonly seen in Gulo (Jung 491 et al., 2016). functionally important and observed in other carnivorans of similar size and ecology. The extant honey badger Mellivora, extinct Eomellivora (Mellivorinae), and Megalictis (Oligobuninae) all display some strong similarity to Gulo and Plesiogulo, despite having distinct evolutionary histories (Zdansky, 1924; Kurtén, 1970; Hendey, 1978; Harrison, 1981; Valenciano et al., 2016; 2017). Superficial similarity of the teeth (robust posterior premolars and carnassials, trenchant talonids, m1 metaconid loss), skull (short rostrum, broad and robust zygomatic arches, prominent sagittal crest), and jaw (deep mandibular corpus) are seen in each of these clades. Additionally, the enamel microstructures of the posterior premolars and molars of Gulo, Plesiogulo, Mellivora, and Eomellivora all display zigzag Hunter-Schreger Bands (Stefen, 2001; Tseng, Wang, \&

502 Stewart, 2009). Independent evolution of similar craniodental morphology and enamel 503 microstructures in these taxa is likely attributable to relatively large body size and similar 504 lifestyles, specifically a hypercarnivorous or durophagous diet (Van Valkenburgh, 1989; Stefen, $5051997 ; 1999)$.

506 Further support for the hypothesized convergence of Gulo and Plesiogulo, rather than 507 close relationship, comes from a variety of molecular studies. The earliest occurrences of 
508 Plesiogulo are in the middle Miocene (MN 6, about 15.2-12.5 Ma; Schmidt-Kittler, 1976). That

509 age predates some molecular estimates for the divergence of the Guloninae from other mustelids,

510 including the approximately 11.0 Ma estimate of Koepfli et al. (2008), but not the $12.65 \mathrm{Ma}$

511 estimate of Sato et al. (2012). However, those early occurrences of Plesiogulo precede the

512 molecular estimates of divergence of the Gulo-Martes clade from other gulonines by nearly 5

513 million years. In contrast, the ages of recently described fossil specimens of Pekania (Wang,

514 Tseng, \& Takeuchi, 2012; Samuels \& Cavin, 2013), and the new Gulo specimen described here,

515 agree broadly with molecular divergence estimates of those extant genera (Koepfli et al., 2008;

516 Hughes, 2012; Sato et al., 2012; Li et al., 2014; Malyarchuk, Derenko, \& Denisova, 2015). In

517 addition, the ages of Gulo sudorus and G. minor are similar to the latest records of Plesiogulo in

518 North America and Asia. Given the timing of these finds, it is possible that Plesiogulo was

519 ecologically replaced by Gulo in the Pliocene. It is important to note that the hypothesized

520 convergence described here is supported by morphological and geochronologic evidence, but is

521 not based on analysis of taxa within a cladistic framework, and is thus speculative.

522

523 'Cold-Adaptation' in Gulo

524 Presence of Gulo, which is typically considered an inhabitant of boreal habitats (Kvam,

525 Overskaug, \& Sorensen, 1988; Pasitschniak-Arts \& Larivière, 1995), at a site with many

526 vertebrate taxa characteristic of warm and/or humid forested habitats (Alligator, Heloderma,

527 Pristinailurus, and Arctomeles) and a subtropical forest flora is a unique combination among

528 North American biotas. An interesting analog is known from the middle Pliocene age (MN16a)

529 Udunga fauna of the Transbaikal area of Russia (Sotnikova \& Kalmykov 1991; Erbajeva,

530 Alexeeva, \& Khenzykhenova, 2003; Sotnikova, 2006; Erbajeva \& Alexeeva, 2013). The Udunga 
531 fauna also has forest-adapted taxa like Parailurus, Parameles, and Arctomeles occurring along

532 with Gulo (Sotnikova, 2006; Ogino et al., 2008; Erbajeva \& Alexeeva, 2013). Another site with

533 Gulo outside its current range is the latest Blancan and Irvingtonian (early Pleistocene) age

534 Vallecito Creek Local Fauna of extreme southern California (Cassiliano, 1999). Like Gray, the

535 Vallecito Creek fauna includes Tapirus and the procyonid, Nasua, which has a current and

536 prehistoric range restricted to the southwestern United States, through Mexico and Central

537 America, and into portions of South America. Occurrences and associated faunas of Gray,

538 Udunga, and Vallecito Creek suggest the boreal distribution of extant Gulo gulo may not

539 represent the potential range of habitats occupied by wolverines, at least in the past. Adaptation

540 to cold, boreal habitats within wolverines may have occurred later, in the late Pliocene or

541 Pleistocene, as global climates became substantially colder and those habitats spread across

542 northern Eurasia and North America.

543

544 Historical Biogeography

545 These finds also have implications for understanding of historical biogeography and

546 evolution of fishers and wolverines. Koepfli et al. (2008) and Zigouris et al. (2013) both estimate

547 Eurasia as the ancestral area for the origin of these taxa, while Sato et al. (2012) restricted the

548 area of origin to Asia. The oldest known probable gulonine is Ischyrictis zibethoides from the

549 Early/Middle Miocene (MN 5-8) of Europe. Early records of Pekania are known from the late

550 Miocene of North America (early Hemphillian) and Asia (Baodean) (Wang, Tseng, \& Takeuchi,

551 2012; Samuels \& Cavin, 2013). Similarly, early records of Gulo are known from the earliest

552 Pliocene (early Blancan) of North America and middle Pliocene (Yushean) of Asia (Sotnikova,

553 1982; 1995). While there are many species of "Martes" described from the Early and Middle 
554 Miocene of Eurasia and North America, the most confidently placed early members of Martes

555 are from the Pliocene (MN 15) of Europe (Stach, 1959; Anderson, 1994; Sato et al., 2003).

556 Earliest members of the tayra clade appear later than the other clades, with Eirictis pachygnatha

557 from the Early Pliocene (Yushean) of Asia (Teilhard de Chardin \& Leroy, 1945; Qiu, Deng, \&

558 Wang, 2004; Wang, Tseng, \& Takeuchi, 2012) and Sminthosinis bowleri from the middle

559 Pliocene (Blancan) of North America.

560 Early members of multiple clades (fisher, wolverine-marten, and tayra) show similar

561 distributions in the late Miocene and Pliocene, occurring in both Asia and North America. This

562 suggests connection of these regions via the Bering Land Bridge at the time, which facilitated

563 dispersal of carnivorans between Asia and North America (Qiu, 2003). Consequently, a

564 hypothesis for intercontinental dispersals of the wolverine clade is: 1) origin of gulonines in

565 Eurasia, 2) dispersal of Pekania from Asia to North America in the late Miocene, 3) divergence

566 of Gulo from an ancestor similar to P. occulta in the earliest Pliocene of North America, 4)

567 dispersal of Gulo to Asia in the Pliocene, following the extinction of Plesiogulo, and 5) dispersal 568 of Gulo to Europe in the Pleistocene.

569

570 CONCLUSIONS

571 The new material of Gulo described here demonstrates the presence of wolverines in the

572 Early Pliocene of North America, more than 1 million years earlier than other known records of

573 the genus. Differences from the extant species and previously described extinct wolverines

574 indicate the presence of a distinct new species, G. sudorus. Similarity of the new species to both

575 early fishers (Pekania) and later Gulo species suggests that this may represent an intermediate

576 form, which evolved in North America and later dispersed to Eurasia. Presence of Gulo in the 
577 Pliocene of Tennessee, at a site with a variety of floral and faunal elements indicative of

578 warm/humid climates, suggests that the 'cold-adapted' nature of extant G. gulo may be a

579 relatively recent phenomenon. Comparisons of Gulo and other members of the Guloninae to

580 Plesiogulo suggest that the latter is not closely related to gulonines, but instead likely represents

581 convergence on a similar niche to that occupied by wolverines. The similar timing of the last

582 records of Plesiogulo with the appearance of Gulo in North America and Asia suggest the former

583 may have been ecologically replaced by the latter in the Early Pliocene.

\section{ACKNOWLEDGEMENTS}

586 The following curators and collection managers kindly allowed access to specimens in their care:

587 A. Nye and B. Compton (ETMNH); K. Molina (Donald R. Dickey Collection of the University

588 of California, Los Angeles); C. Conroy (University of California, Berkeley - Museum of

589 Vertebrate Zoology); J. Dines (Museum of Natural History, Los Angeles County); B. Akersten

590 and M. Thompson (Idaho Museum of Natural History); and M. Brett-Surman and L. Gordon

591 (National Museum of Natural History).

592

\section{REFERENCES}

594 Alcalá L, Montoya P, Morales J. 1994. New large mustelids from the Late Miocene of Teruel Basin (Spain). Comptes Rendus de l'Académie des Sciences de Paris 319, série II:1093$596 \quad 1100$.

597 Anderson E. 1970. Quaternary evolution of the genus Martes (Carnivora, Mustelidae). Acta 598 Zoologica Fennica 130:1-132. 
599 Anderson E. 1994. Evolution, prehistoric distribution and systematics of Martes. In: Buskirk 600 SW, Harestad AS, Raphael MG, Powell RA, eds. Martens, Sables and Fishers: Biology 601 and Conservation. Ithaca, New York: Cornell University Press, 13-25.

602 Anderson E. 1998. Quaternary wolverines (Gulo gulo) from Idaho. In Akersten WA, McDonald 603 HG, Meldrum DJ, Flint MET, eds. Papers on the vertebrate paleontology of Idaho honoring John H. White, Volume 1, Idaho Museum of Natural History Occasional Paper $36,173-185$.

Baryshnikov GF. 2015. Late Pleistocene Ursidae and Mustelidae remains (Mammalia, Carnivora) from Geographical Society Cave in the Russian Far East. Proceedings of the Zoological Institute RAS 319(1):3-22.

Baskin JA. 1998. Mustelidae. In Janis CM, Scott KM, and Jacobs LL, eds. Evolution of Tertiary Mammals of North America, Volume 1: Terrestrial Carnivores, Ungulates, and

612 Bell CJ, Lundelius EL Jr, Graham RW, Barnosky AD, Lindsay EH, Ruez DR Jr, Semken HA Jr, Webb SD, Zakrzewski RJ, Woodburne MO. 2004. The Blancan, Irvingtonian, and Ungulatelike Mammals. Cambridge: Cambridge University Press, 152-173.

617 Bjork PR. 1970. The Carnivora of the Hagerman local fauna (late Pliocene) of southwestern 618 Idaho. Transactions of the American Philosophical Society 60(7):3-54.

619 Boardman GS, Schubert BW. 2011. First Mio-Pliocene salamander fossil assemblage from the 620 southern Appalachians. Palaeontologia Electronica 14(2): p.16A. 
621 Bonifay MF. 1971. Carnivores Quaternaires du Sud-Est de la France. Mémoires du Muséum $622 \quad$ National d'Histoire Naturelle 21:43-377.

623 Bourque JR, Schubert BW. 2015. Fossil musk turtles (Kinosternidae, Sternotherus) from the late 624 Miocene-early Pliocene (Hemphillian) of Tennessee and Florida. Journal of Vertebrate $625 \quad$ Paleontology 35(1):p.e885441.

626 Bowdich TE. 1821. An analysis of the natural classifications of Mammalia for the use of 627 students and travelers. Paris: J. Smith.

Brandon S. 2013. Discovery of bald cypress fossil leaves at the Gray Fossil Site, Tennessee and their ecological significance. Undergraduate honors thesis, East Tennessee State University.

Bryant HN. 1987. Wolverine from Pleistocene of the Yukon: evolutionary trends and taxonomy 632 of Gulo (Carnivora: Mustelidae). Canadian Journal of Earth Sciences 24:654-663.

633 Carrasco MA, Barnosky AD, Kraatz BP, Davis EB. 2007. The Miocene mammal mapping 634 project (MIOMAP): an online database of Arikareean through Hemphillian fossil mammals. Bulletin of the Carnegie Museum of Natural History 39:183-188.

636 Cassiliano MJ. 1999. Biostratigraphy of Blancan and Irvingtonian mammals in the Fish CreekVallecito section, southern California, and a review of the Blancan-Irvingtonian boundary. Journal of Vertebrate Paleontology 19:169-186.

Dahlquest WW. 1978. Early Blancan mammals of the Beck Ranch Local Fauna of Texas. Journal of Mammalogy 59:269-298.

641 Dehm R. 1950. Die Raubtiere aus dem Mittel-Miozän (Burdigalium) von Wintershof-West bei 642 Eichstätt in Bayern. Abhandlungen der Bayerischen Akademie der Wissenschaften, Mathematisch-naturwissenschaftliche Klasse, Neue Folge 58:1-141. 
644 DeSantis LR, Wallace SC. 2008. Neogene forests from the Appalachians of Tennessee, USA:

645

646

647

648

649

650

651

652

653

654

655

656

657

658

659

660

661

662

663

664

665

666

geochemical evidence from fossil mammal teeth. Palaeogeography, Palaeoclimatology, Palaeoecology 266(1):59-68.

Döppes D. 2001. Gulo gulo (Mustelidae, Mammalia) im Jungpleistozän Mitteleuropas. Beiträge zur Paläontologie 26:1-95.

Erbajeva M, Alexeeva N, Khenzykhenova F. 2003. Pliocene small mammals from the Udunga site of the Transbaikal area. Coloquious de Paleontologia 1:133-145.

Erbajeva M, Alexeeva N. 2013. Late Cenozoic Mammal Faunas of the Baikalian Region: Composition, Biochronology, Dispersal, and Correlation with Central Asia. Wang X, Flynn LJ, eds. Fossil Mammals of Asia: Neogene Biostratigraphy and Chronology. New York: Columbia University Press, 495-507.

Eshelman RE, Whitmore Jr FC. 2008. Early Pliocene (Late Hemphillian) Land Mammals from the Lee Creek Mine, Aurora, North Carolina. Geology and Paleontology of the Lee Creek Mine, North Carolina, IV. Virginia Museum of Natural History Special Publication $14: 17-38$.

Farlow JO, Sunderman JA, Havens JJ, Swinehart AL, Holman JA, Richards RL, Miller NG, Martin RA, Hunt Jr RM, Storrs GW, Curry BB. 2001. The Pipe Creek Sinkhole biota, a diverse late Tertiary continental fossil assemblage from Grant County, Indiana. The American Midland Naturalist 145(2):367-78.

Fischer von Waldheim G. 1817. Adversaria zoologica. Mémoires de la Société Imperiale des Naturalistes de Moscou 5:357-472.

Fortelius M. 2013. New and Old Worlds Database of Fossil Mammals (NOW). University of Helsinki. Available at http://www.helsinki.fi/science/now/ (Accessed 9 November 2017). 
667 Gidley JW, Gazin CL. 1933. New Mammalia in the Pleistocene Fauna from Cumberland Cave. $668 \quad$ Journal of Mammalogy 14(4):343-357.

669 Gidley JW, Gazin CL. 1938. The Pleistocene vertebrate fauna from Cumberland Cave, $670 \quad$ Maryland. Unites States National Museum Bulletin 171:1-99.

671 Ginsburg L. 1999. Order Carnivora. Land Mammals of Europe. Rössner GE, Heissig K, eds. 672 München: Pfeil, 109-148.

673 Ginsburg L, Morales J. 1992. Contribution à la connaissance des Mustélidés (Carnivora, 674 Mammalia) du Miocène d'Europe Trochictis et Ischyrictis, genres affines et genres nouveaux. Comptes Rendus de l'Académie des Sciences de Paris 315, série II:111-116.

676 Graham RW, Lundelius EL Jr. 2010. FAUNMAP II: New Data for North America with a Temporal Extension for the Blancan, Irvingtonian and early Rancholabrean. FAUNMAP II Database, version 1.0. Available at http://www.ucmp.berkeley.edu/faunmap (Accessed

679 9 November 2017).

Gray JE. 1825. On the natural arrangement of vertebrose animals. The London Medical Repository Monthly Journal and Review 15:296-310.

682 Gustafson EP. 2012. New records of rhinoceroses from the Ringold Formation of central 683 684 Washington and the Hemphillian-Blancan boundary. Journal of Vertebrate Paleontology $32: 727-731$.

685 Haile-Selassie Y, Hlusko LJ, Howell FC. 2004. A new species of Plesiogulo (Mustelidae: Carnivora) from the Late Miocene of Africa. Palaeontologia Africana, 40:85-88. Hall ER. 1936. Mustelid Mammals from the Pleistocene of North America. Carnegie Institute of 688 Washington, Publication 473:41-119. 
689 Harrison JA. 1981. A Review of the extinct wolverine, Plesiogulo (Carnivora: Mustelidae), from 690 North America. Smithsonian Contributions to Paleobiology 46:1-27.

691 Hendey QB. 1978. Late Tertiary Mustelidae (Mammalia, Carnivora) from Langebaanweg, South 692 Africa. Annals of the South African Museum 76(10):329-357.

693 694 695 696 697 698

Hughes SS. 2012. Synthesis of Martes evolutionary history. In Aubry KB, Zielinski WJ, Raphael MG, Proulx G, Buskirk SW, eds. Biology and Conservation of Martens, Sables, and Fishers. Ithaca: Comstock Publishing Associates, Cornell University Press, 3-22.

Janis CM, Manning E. 1998. Dromomerycidae. In C. M. Janis, K. M. Scott, and L. L. Jacobs (eds.), Evolution of Tertiary Mammals of North America. Cambridge University Press, Cambridge, 477-490.

Jasinski SE. 2013. Fossil Trachemys (Testudines: Emydidae) from the Late Hemphillian of Eastern Tennessee and its implications for the evolution of the Emydidae. MS thesis, East Tennessee State University.

Jung TS, Rivest G, Blakeburn DA, Hamm ER, van Eyk A, Kukka PM, Robitaille J. 2016. Dental anomalies suggest an evolutionary trend in the dentition of wolverine (Gulo gulo). Mammal Research 61(4):361-366.

Kalmykov NP. 2015. Mammals of the framing of Lake Baikal in the fossil record, carnivores (Carnivora, Mammalia). The Baikal Zoological Journal 16(1):58-70.

Koepfli K-P, Deere KA, Slater GJ, Begg C, Begg K, Grassman L, Lucherini M, Veron G, Wayne RK. 2008. Multigene phylogeny of the Mustelidae: Resolving relationships, tempo and biogeographic history of a mammalian adaptive radiation. BMC Biology 6(10):1-22.

Kolfshoten TV. 2001. A fossil wolverine Gulo schlosseri (Carnivora, Mustelidae) from Nieuwegein, The Netherlands. Lynx (Praha) 32:183-191. 
712 Kormos T. 1914. Drei neue Raubtiere aus den Präglazial-Schichten des Somlyóhegy bei

713 Püspökfürdö. Annals of the Hungarian State Geological Institute 22:223-247.

714 Koufos GD. 1982. Plesiogulo crassa from the Upper Miocene (Lower Turolian) of Northern

715 Greece. Annales Zoologici Fennici 19:193-197.

716 Koufos GD. 2000. Revision of the late Miocene carnivores from the Axios valley, Macedonia,

717 Greece. Münchner Geowissenschaftliche Abhandlungen 39(A):51-92.

718 Krajcarz MT. 2012. Small fossil wolverine Gulo from Middle Pleistocene of Poland. Acta

719 Zoologica Cracovensis 55(1):79-87.

720 Kurtén B. 1970. The Neogene wolverine Plesiogulo and the origin of Gulo (Carnivora,

721 Mammalia). Acta Zoologica Fennica 131:1-22.

722 Kurtén B. 1973. Fossil glutton (Gulo gulo (L.)) from Tornewton Cave, South Devon.

723 Commentationes Biologicae 66:1-8.

724 Kurtén B, Anderson E. 1980. Pleistocene Mammals of North America. New York: Columbia $725 \quad$ University Press.

726 Kvam R, Overskaug K, and Sorensen OJ. 1988. The wolverine Gulo gulo in Norway. Lutra $727 \quad 31: 7-20$.

728 Li B, Wolsan M, Wu D, Zhang W, Xu Y, Zeng Z. 2014. Mitochondrial genomes reveal the pattern and timing of marten (Martes), wolverine (Gulo), and fisher (Pekania)

730 diversification. Molecular Phylogenetics and Evolution 80:156-164.

731 Lindsay EH. 2008. Cricetidae. In Janis CM, Gunnell GF, Uhen MD, eds. Evolution of Tertiary 732 Mammals of North America Vol. 2: Small Mammals, Xenarthrans, and Marine Mammals. New York: Cambridge University Press, 456-479. 
734 Linnaeus C. 1758. Systema naturae per regna tria naturae, secundum classes, ordines, genera, 735 species, cum characteribus, differentiis, synonymis, locis. Vol. 1: Regnum animale. Editio 736 decima, 1758. Stockholm: Societatis Zoologicae Germanicae.

737 Madden CT, Dahlquest WW. 1990. The last rhinoceros in North America. Journal of Vertebrate 738 Paleontology 10:266-267.

739

740

741

742

743

744

745

746

747

748

749

750

751

752

753

754

755

Malyarchuk BA, Derenko MV, Denisova GA. 2015. Mitochondrial genome variability in the wolverine (Gulo gulo). Russian Journal of Genetics 51(11):1113-1118.

Martin RA. 2000. The taxonomic status of Peromyscus sawrockensis Hibbard, 1964. Paludicola, 2:269-272.

Martin RA, Goodwin HT, Farlow JO. 2002. Late Neogene (Late Hemphillian) rodents from the Pipe Creek Sinkhole, Grant County, Indiana. Journal of Vertebrate Paleontology 22(1):137-151.

Martin RA. 2010. The North American Promimomys immigration event. Paludicola 8(1):14-21.

Martin RA, Peláez-Campomanes P. 2014. Diversity dynamics of the late Cenozoic rodent community from southwestern Kansas: the influence of historical processes on community structure. Journal of Quaternary Science 29:221-231.

Martin RA, Peláez-Campomanes P, Viriot L. 2017. First report of rodents from the late Hemphillian (late Miocene) Zwiebel Channel and a revised late Neogene biostratigraphy/biochronology of the Sand Draw area of Nebraska. Historical Biology, DOI:10.1080/08912963.2017.1313251

Marx FG, Fordyce RE. 2015. Baleen boom and bust: a synthesis of mysticete phylogeny, diversity and disparity. Royal Society Open Science 2(4):140434. 
756 Mead JI, Schubert BW, Wallace SC, and Swift SL. 2012. Helodermatid lizard from the Mio-

757 Pliocene oak-hickory forest of Tennessee, eastern USA, and a review of monstersaurian $758 \quad$ osteoderms. Acta Palaeontologica Polonica 57:111-121.

759 Montoya P, Morales J, Abella J. 2011. Musteloidea (Carnivora, Mammalia) del Mioceno

760 Superior de Venta del Moro (Valencia, España). Estudios Geológicos 67(2):193-206.

761 Nadachowski A, Stefaniak K, Szynkiewicz A, Marciszak A, Socha P, Schick P, August C. 2011.

762 Biostratigraphic importance of the Early Pleistocene fauna from Zabia Cave (Poland) in

763 Central Europe. Quaternary International 243:204-218.

764 Ochoa D, Whitelaw M, Liu YS, and Zavada M. 2012. Palynology from Neogene sediments at

765 the Gray Fossil Site, Tennessee, USA: Floristic implications. Review of Palaeobotany

$766 \quad$ and Palynology 184:36-48.

767 Ochoa D, Zavada MS, Liu Y, Farlow JO. 2016. Floristic implications of two contemporaneous

768

769 inland upper Neogene sites in the eastern US: Pipe Creek Sinkhole, Indiana, and the Gray

770 Fossil Site, Tennessee (USA). Palaeobiodiversity and Palaeoenvironments 96(2):239-

771

Ogino S, Nakaya H, Takai M, Fukuchi A. 2008. Notes on carnivore fossils from the Pliocene 772

Pallas PS. 1780. Spicilegia zoologica, quibus novae imprimus et obscurae animalium species Udunga fauna, Transbaikal area, Russia. Asian Paleoprimatology 5:45-60. iconibus, descriptionibus atque commentariis illustrantur cura P.S. Pallas. New York,

Parmalee PW, Klippel WE, Meylan PA, Holman JA. 2002. A late Miocene-early Pliocene population of Trachemys (Testundines: Emydidae) from east Tennessee. Annals Carnegie Museum 71:233-239 
779 Pasitschniak-Arts M, Larivière S. 1995. Gulo gulo. Mammalian Species 499:1-10.

780 Peigné S. 2012. Les Carnivora de Sansan. In Peigné S, Sen S, eds. Mammifères de Sansan. Paris:

781 Muséum National d'Histoire Naturelle: 559-660 (Mémoires du Muséum national

782 d'Histoire naturelle, 203).

783 Prothero DR. 2005. The Evolution of North American Rhinoceroses. Cambridge: Cambridge

$784 \quad$ University Press.

785 Prothero DR, Manning EM. 1987. Miocene rhinoceroses from the Texas Gulf Coastal Plain. Journal of Paleontology 61:388-423.

787 Qiu, Z-X. 2003. Dispersals of Neogene carnivorans between Asia and North America. In Flynn LJ ed. Vertebrate Fossils and Their Context: Contributions in Honor of Richard H. Tedford. Bulletin of the American Museum of Natural History 279:18-31.

790 Qiu Z, Deng T, Wang B. 2004. Early Pleistocene mammalian fauna from Longdan, Dongxiang, Gansu, China. Palaeontologia Sinica, New Series C 27:1-198.

792 Samuels JX, Cavin J. 2013. The earliest known fisher (Mustelidae), a new species from the Rattlesnake Formation of Oregon. Journal of Vertebrate Paleontology 33(2):448-454.

794 Sato JJ, Hosoda T, Wolsan M, Tsuchiya K, Yamamoto M, Suzuki H. 2003. Phylogenetic 795 relationships and divergence times among mustelids (Mammalia: Carnivora) based on nucleotide sequences of the nuclear interphotoreceptor retinoid binding protein and mitochondrial cytochrome $b$ genes. Zoological Science 20:243-264.

Sato JJ, Wolsan M, Prevosti FJ, D’Elía G, Begg C, Begg K, Hosoda T, Campbell KL, Suzuki H. 799 2012. Evolutionary and biogeographic history of weasel-like carnivorans (Musteloidea). Molecular Phylogenetics and Evolution 63:745-757. 
801 Schlosser M. 1924. Tertiary vertebrates from Mongolia. Palaeontologia Sinica, Series C 1:1$802 \quad 132$.

803 Schmidt-Kittler N. 1976. Raubtiere aus dem Jungtertïar Kleinasiens. Palaeontographica 155:1$804 \quad 131$.

805 Shunk AJ, Driese SG, Clark GM. 2006. Latest Miocene to earliest Pliocene sedimentation and 806 climate record derived from paleosinkhole fill deposits, Gray Fossil Site, northeastern 807 Tennessee, U.S.A. Palaeogeography, Palaeoclimatology, Palaeoecology 231:265-278.

808 Shunk AJ, Driese SG, Dunbar JA. 2009. Late Tertiary paleoclimatic interpretation from 809 lacustrine rhythmites in the Gray Fossil Site, northeastern Tennessee, USA. Journal of $810 \quad$ Paleolimnology $42: 11-24$

811 Sotnikova MV. 1982. On the history of the genus Gulo in Eurasia. Trudy Zoologicheskogo $812 \quad$ Instituta Akademii Nauk SSSR 111:65-73.

813 Sotnikova MV. 1995. Extinct wolverine from the former USSR: review of the genus Plesiogulo 814 (Carnivora: Mustelidae). Lutreola 6:1-8.

815 Sotnikova MV. 2006. Pliocene-Early Pleistocene Carnivora assemblages of Transbaikalian 816 Area, Russia. Stratigraphy, Paleontology and Paleoenvironment of Pliocene-Pleistocene 817 of Transbaikalia and Interregional Correlations. Ulan: Ude, 84-85.

818 Sotnikova MV, Kalmykov NP. 1991. Pliocene Carnivora from Udunga locality (Transbaikalia, 819 USSR). In Vangengeim EA, ed. Pliocene and Anthropogene Paleogeography and 820 Biostratigraphy. Geological Institute: Moscow, 146-160.

821 Stach J. 1959. On some Mustelinae from the Pliocene bone breccia of Węże. Acta 822 Palaeontologica Polonica IV(2):101-120. 
823 Stefen C. 1997. Differentiations in Hunter-Schreger bands of Carnivores. In von Koenigswald 824 W, Sander PM, eds. Tooth enamel microstructure. Rotterdam: A.A. Balkema, 123-136.

825 Stefen C. 1999. Enamel structure of Recent and fossil Canidae (Carnivora, Mammalia). Journal 826 of Vertebrate Paleontology 19:576-588.

827 Stefen C. 2001. Enamel structure of arctoid Carnivora: Amphicyonidae, Ursidae, Procyonidae, $828 \quad$ and Mustelidae. Journal of Mammalogy 82:450-462.

829 Stehlin HG. 1931. Paléontologie des couches paléolithiques. In Dubois A \& Stehlin HG. La 830 grotte de Cotencher, Station Mousterienne, Premiere partie, Mémoires de la Société $831 \quad$ Paléontologique Suisse 52:33-178.

832 Teilhard de Chardin P, Leroy P. 1945. Les Mustélidés de Chine. Publications de l'Institut de $833 \quad$ Géobiologie 12:1-56.

834 Tseng ZJ, O'Connor JK, Wang X, Prothero DR. 2009. The first old world occurrence of the 835 836 North American mustelid Sthenictis (Mammalia, Carnivora). Geodiversitas 31(4):743Tseng ZJ, Wang X, Stewart JD. 2009. A new immigrant mustelid (Carnivora, Mammalia) from the middle Miocene Temblor Formation of central California. PaleoBios 29(1).

839 Valenciano A, Baskin JA, Abella J, Pérez-Ramos A, Álvarez-Sierra MÁ, Morales J, Hartstone840 Rose A. 2016. Megalictis, the bone-crushing giant mustelid (Carnivora, Mustelidae, 841 Oligobuninae) from the Early Miocene of North America. PloS one 11(4):e0152430.

842 Valenciano A, Abella J, Göhlich UB, Álvarez-Sierra MÁ, Morales J. 2017. Re-evaluation of the 843 very large Eomellivora fricki (Pia, 1939)(Carnivora, Mustelidae, Mellivorinae) from the 844 Late Miocene of Austria. Palaeontologia Electronica 20(1):1-22. 
845 Van Valkenburgh B. 1989. Carnivore dental adaptations and diet: study of trophic diversity 846 within guilds. In Gittleman JL, ed. Carnivore behavior, ecology, and evolution. New 847 York: Cornell University Press, 410-436.

848 Viret J. 1939. Monographie Paléontologique de la Faune de Vertebrés des Sables de Montpellier. 849 III. Carnivora Fissipedia. Travaux du Laboratoire de Géologie de la Faculte des Sciences 850 de Lyon 37:7-26.

851 Voorhies MR. 1990. Vertebrate biostratigraphy of the Ogallala Group in Nebraska. Geologic 852 Framework and Regional Hydrology, 115-151.

853 Wallace SC, Wang X. 2004. Two new carnivores from an unusual late Tertiary forest biota in 854 eastern North America. Nature 431:556-559.

855 Wang X, Tseng ZJ, Takeuchi GT. 2012. Zoogeography, Molecular Divergence, and the Fossil 856 Record - the Case of an Extinct Fisher, Pekania palaeosinensis (Mustelidae, Mammalia), from the Late Miocene Baogeda Ula Formation, Inner Mongolia. Vertebrata PalAsiatica 50(003):293-307.

860

Webb SD. 1969. The Burge and Minnechaduza Clarendonian Mammalian Fauns of NorthCentral Nebraska. University of California Publications in Geological Sciences 78:1-191.

862 Fauna (early Pliocene, latest Hemphillian) from the central Florida phosphate district. 863 Natural History Museum Los Angeles County Science Series 41:293-312.

864 Wolsan M. 1988. Morphological variations of the first upper molar in the genus Martes 865 (Carnivora, Mustelidae). Mémoires du Muséum National d'Histoire Naturelle, Série C $866 \quad 53: 241-254$ 
867 Wolsan M. 1989a. Drapieżne-Carnivora. In Kowalski K, ed. Historia I ewolucja la dowej fauny 868 Polski, Folia Quatern 59-60, 177-196.

869 Wolsan M. 1989b. Dental polymorphism in the genus Martes (Carnivora: Mustelidae) and its 870 evolutionary significance. Acta Theriologica 34(40):545-593.

871 Wolsan M. 1993. Phylogeny and classification of early European Mustelida (Mammalia: 872 Carnivora). Acta Theriologica 38(4):345-384.

873 Wolsan M, Ruprecht AL, Buchalczyk T. 1985. Variation and asymmetry in the dentition of the 874 pine and stone martens (Martes martes and M. foina) from Poland. Acta Theriologica 30(3):79-114.

Wolsan M, Sato JJ. 2010. Effects of data incompleteness on the relative performance of parsimony and Bayesian approaches in a supermatrix phylogenetic reconstruction of Mustelidae and Procyonidae (Carnivora). Cladistics 26:168-94.

879 Worobiec E, Liu Y, Zavada MS. 2013. Palaeoenvironment of late Neogene lacustrine sediments 880 at the Gray Fossil Site, Tennessee, U.S.A. Annales Societatis Geologorum Poloniae $83: 51-63$.

Xu X, Wei H. 1987. Fossil Gulo in China. Vertebrata PalAsiatica 25(4):306-315.

884 Zhu S, Gao Y, Liu H, Zhang S, Bai X, Zhang M. 2016. Phylogenetic relationship of wolverine 885 Gulo gulo in Mustelidae revealed by complete mitochondrial genome. Mitochondrial DNA Part A 27(4):2937-2938.

887 Zigouris J, Schaefer JA, Fortin C, Kyle CJ. 2013. Phylogeography and post-glacial recolonization in wolverines (Gulo gulo) from across their circumpolar distribution, PLoS One 8:e83837. 
890 Zobaa MK, Zavada MS, Whitelaw M, Shunk AJ, Oboh-Ikuenobe FE. 2011. Palynology and 891 palynofacies analyses of the Gray Fossil Site, eastern Tennessee: their role in 892 understanding the basin-fill history. Palaeogeography, Palaeoclimatology, $893 \quad$ Palaeoecology 308(3-4):433-444. 


\section{FIGURE CAPTIONS}

895 Figure 1. Distribution of Gulo through time in (A) North America and (B) Eurasia. Current 896 range (light gray) and historic range (medium gray) are based on Pasitschniak-Arts and Larivière 897 1995, Ziguoris et al. 2013; Pleistocene range (dark gray) is based on localities where fossils of 898 Gulo have been found and reported in a wide range of literature sources. The only two known 899 Pliocene occurrences, the Gray Fossil Site in Tennessee and Udunga Fauna of Russia, are 900 highlighted with an asterisk. Terrain base map from ESRI ArcMap 10.5 [Intended for full page 901 width].

902

903

Figure 2. Stratigraphic ranges of selected mammals from the Gray Fossil Site in Tennessee. The 904 black bars indicate stratigraphic ranges of genera and species based on first and last appearance 905 dates (data sources are listed in the Geologic Setting section). Overlap in ranges of taxa, between 4.9 and 4.5 Ma, is highlighted with a gray bar. [Intended for full page width]

907

Figure 3. Holotype of Gulo sudorus (ETMNH 3663) from the Gray Fossil Site, Tennessee. Specimen consists of a right P2 and maxilla fragment with P4. (A) Lateral view. (B) Occlusal view. (C) Original illustration of the specimen by Keila Bredehoeft. Scale bar equals $1 \mathrm{~cm}$.

911 Photographs by Joshua Samuels. [Intended for full page width]

912

913 Figure 4. Occlusal morphology of gulonine mustelids and Plesiogulo. (A) Gulo gulo (ETVP

914 291). (B) Pekania pennanti (ETVP 601). (C) Plesiogulo marshalli (composite of FAM 23386

915 and 49230). (D) Martes americana (NAUQSP 2015). Images are scaled to the same P2 - M1 916 length. Original illustrations by Keila Bredehoeft. [Intended for full page width] 
917 Figure 5. Phylogeny of gulonine mustelids with estimated divergence times and geologic ages of

918 known fossils. Phylogenetic relationships of extant taxa based on cladistics analyses of Koepfli

919 et al., 2008; Sato et al., 2012; and Li et al., 2014. Note that the placements of extinct taxa are not

920 based on a cladistic analysis, rather they are based morphological comparisons made in this

921 manuscript and prior studies. Divergence times (indicated by horizontal boxes) are based on

922 protein coding region data set in Li et al. (2014), except divergence time of Guloninae from other 923 "crown" mustelids (Helictidinae, Ictonychinae, Lutrinae, and Mustelinae) based on multidivtime

924 analysis of Sato et al. (2012). Age ranges of fossil taxa (thick black lines) are based on

925 occurrences and references listed in Supplemental Table 1 and data sources listed in the Geologic

926 Setting section. [Intended for full page width]

927

928 Figure 6. Gulo gulo (ETVP 269) with an atavistic external median rootlet on the upper P4,

929 which is exposed through the lateral surface of the maxilla. Scale bar equals $1 \mathrm{~cm}$. Photograph by

930 Joshua Samuels. [Intended for column width]

931

932 


\section{TABLE CAPTIONS}

934 Table 1. Dental measurements (in $\mathrm{mm}$ ) of gulonines and some other mustelid species.

935 Measurements derived from literature sources include the following: Gulo gulo (Holocene) from 936 Anderson (1998), G. gulo (Pleistocene) from Döppes (2001) and Baryshnikov (2015), G.

937 schlosseri from Gidley \& Gazin (1938) (“Gulo gidleyi”) and Bonifay (1971), Iberictis azanzae

938 from Ginsburg \& Morales (1992), Plesiogulo brachygnathus from Zdansky (1924), P. crassa

939 and $P$. praecocidens from Kurtén (1970), P. lindsayi and P. marshalli from Harrison (1981), P.

940 monspessulanus from Hendey (1978), P. botori from Haile-Selassie, Hlusko, \& Howell (2004),

941 Sminthosinis bowleri from Bjork 1970. Pekania diluviana from Gidley \& Gazin (1933), P.

942 palaeosinensis from Zdansky (1924) and Wang, Tseng, \& Takeuchi (2012), Ischyrictis

943 zibethoides from (Peigné 2012), Martes ginsburgi from Montoya, Morales, \& Abella (2011), and

944 M. wenzensis from Stach (1959). Complete listing of measurements for individuals are included

945 in Supplemental Table 2.

946 


\section{SUPPLEMENTAL MATERIAL}

948 Supplemental Figure 1. Gulo gulo (ETVP 291) photographed in two different orientations. (A)

949 Palate parallel to the photographic plane. (B) Alveolar margin of P4 parallel to the photographic

950 plane. Note that in A the lingual cingulum along the P4 metastyle is obscured, but it is visible in

951 B. Scale bar equals $1 \mathrm{~cm}$. Photographs by Joshua Samuels. [Intended for full page width]

952

953 Supplemental Table 1. Occurrences of Gulo in the fossil records of North America and Eurasia.

954 Data were derived from a wide range of literature sources, as well as occurrences listed in the

955 MIOMAP/FAUNMAP Databases (Carrasco et al., 2007; Graham \& Lundelius, 2010;

956 http://www.ucmp.berkeley.edu/neomap/) and NOW Database (Fortelius, 2013;

957 http://pantodon.science.helsinki.fi/now/).

958

959 Supplemental Table 2. Dental measurements (in $\mathrm{mm}$ ) of gulonines and some other mustelid

960 species used in comparative analyses. Data were derived from measurements of specimens and

961 consultation of cited literature sources.

962

963 


\section{Figure 1}

Distribution of Gulo through time in (A) North America and (B) Eurasia.

Current range (light gray) and historic range (medium gray) are based on Pasitschniak-Arts and Larivière 1995, Ziguoris et al. 2013; Pleistocene range (dark gray) is based on localities where fossils of Gulo have been found and reported in a wide range of literature sources. The only two known Pliocene occurrences, the Gray Fossil Site in Tennessee and Udunga Fauna of Russia, are highlighted with an asterisk. Terrain base map from ESRI ArcMap 10.5.

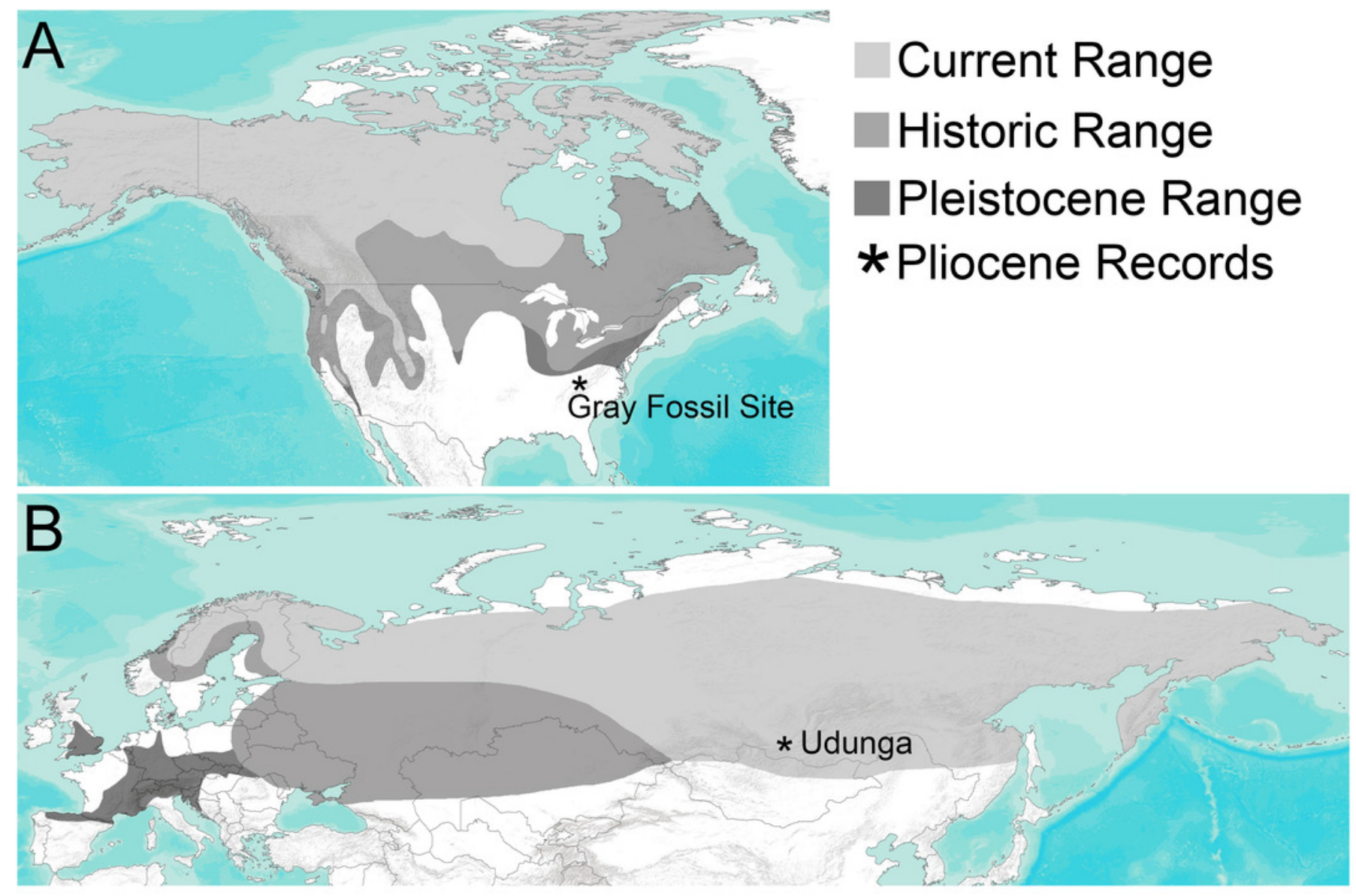


Figure 2

Stratigraphic ranges of selected mammals from the Gray Fossil Site in Tennessee.

The black bars indicate stratigraphic ranges of genera and species based on first and last appearance dates (data sources are listed in the Geologic Setting section). Overlap in ranges of taxa, between 4.9 and $4.5 \mathrm{Ma}$, is highlighted with a gray bar.

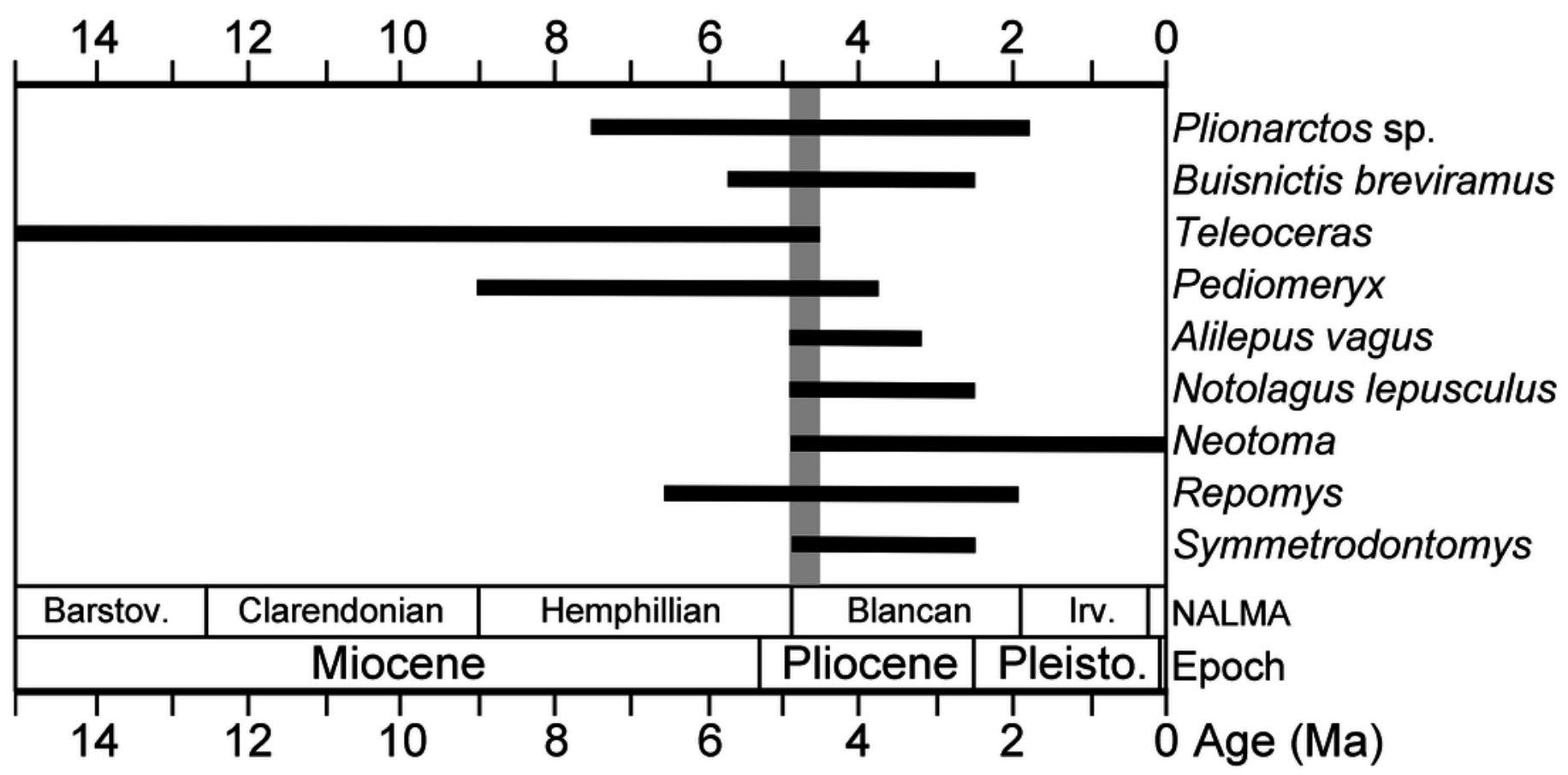




\section{Figure 3}

Holotype of Gulo sudorus (ETMNH 3663) from the Gray Fossil Site, Tennessee.

Specimen consists of a right P2 and maxilla fragment with P4. (A) Lateral view. (B) Occlusal view. (C) Original illustration of the specimen by Keila Bredehoeft. Scale bar equals $1 \mathrm{~cm}$. Photographs by Joshua Samuels. 


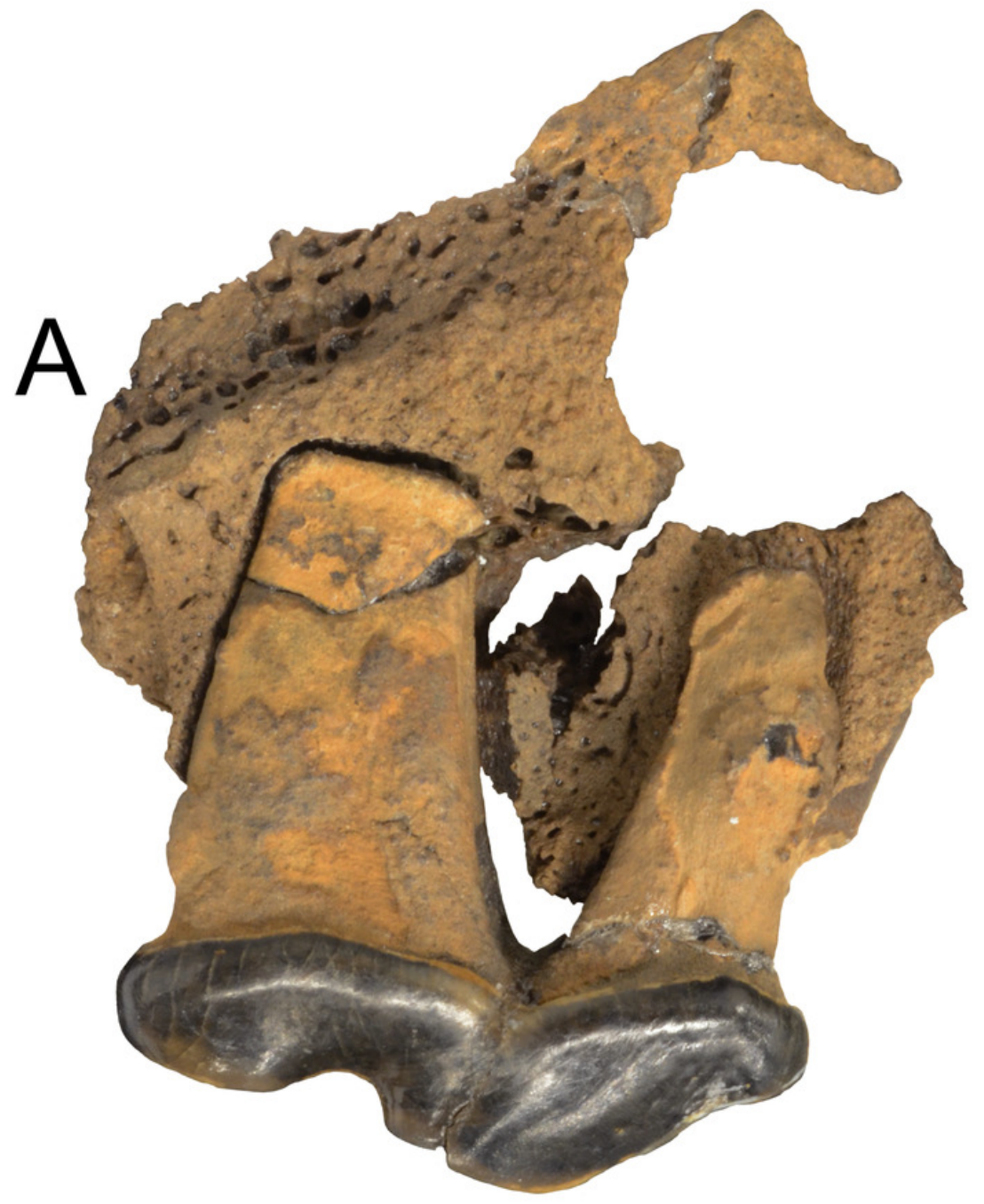

\section{$1 \mathrm{~cm}$}

B
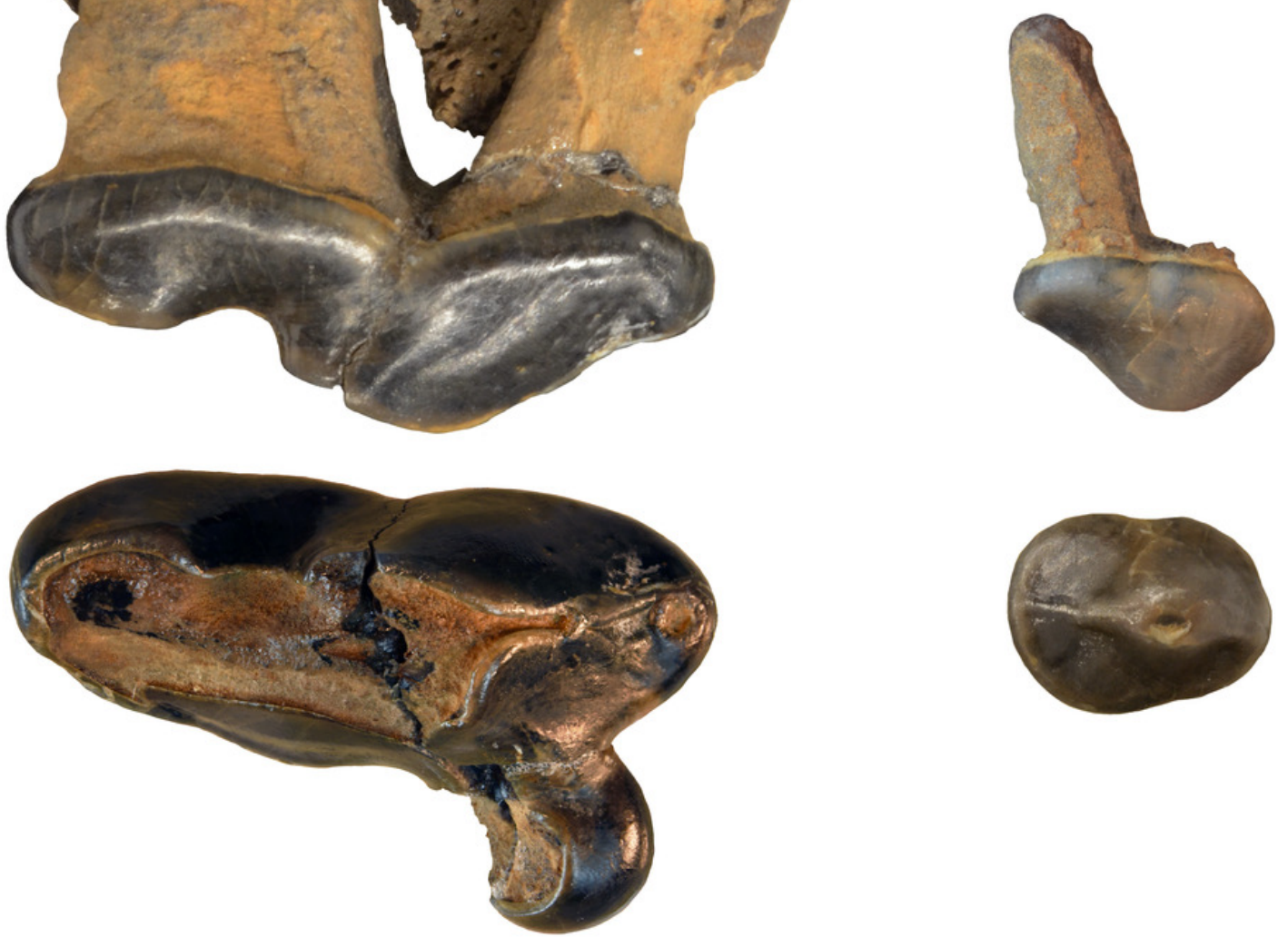

C
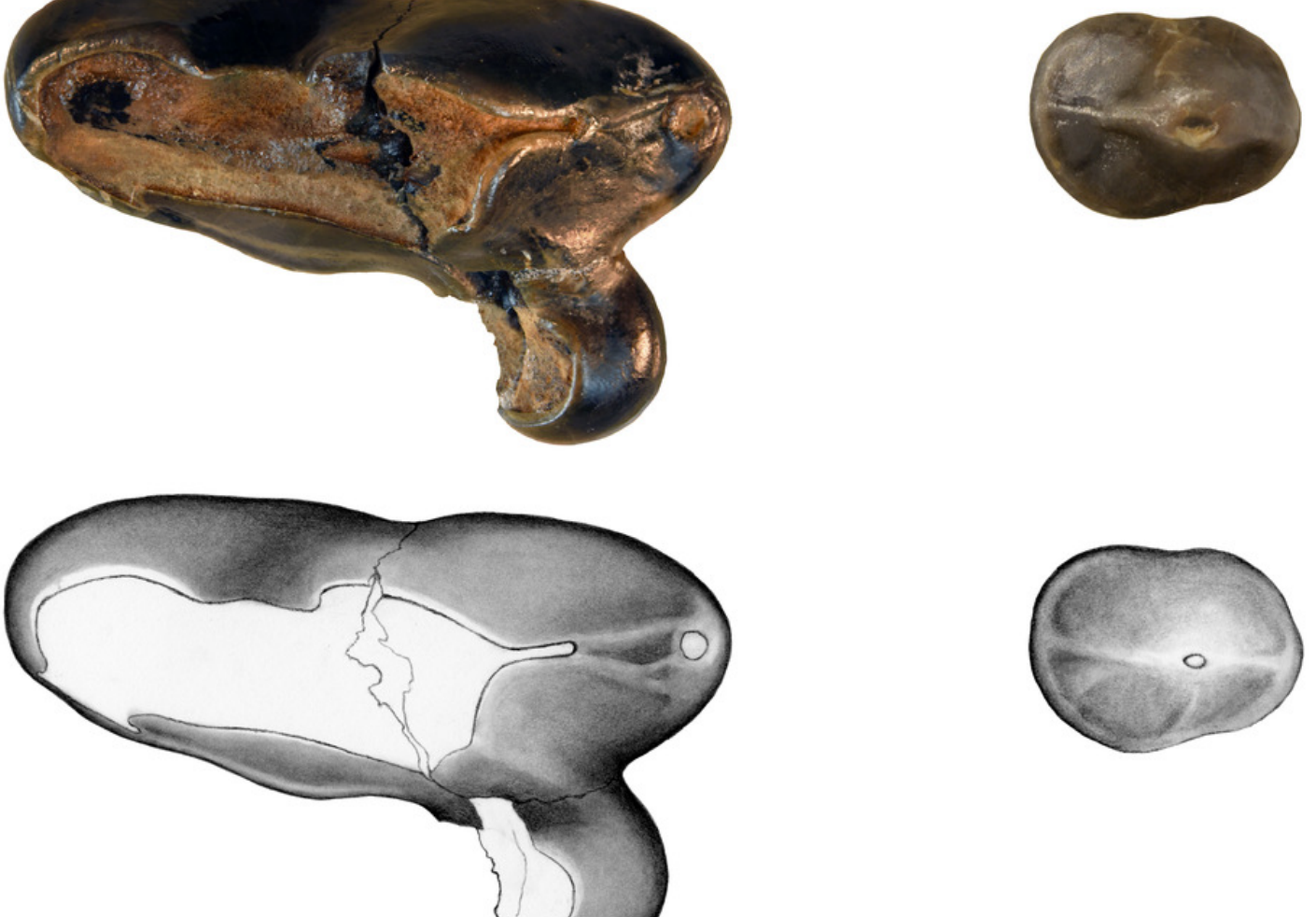
Figure 4

Occlusal morphology of gulonine mustelids and Plesiogulo.

(A) Gulo gulo (ETVP 291). (B) Pekania pennanti (ETVP 601). (C) Plesiogulo marshalli (composite of FAM 23386 and 49230). (D) Martes americana (NAUQSP 2015). Images are scaled to the same P2 - M1 length. Original illustrations by Keila Bredehoeft.

A

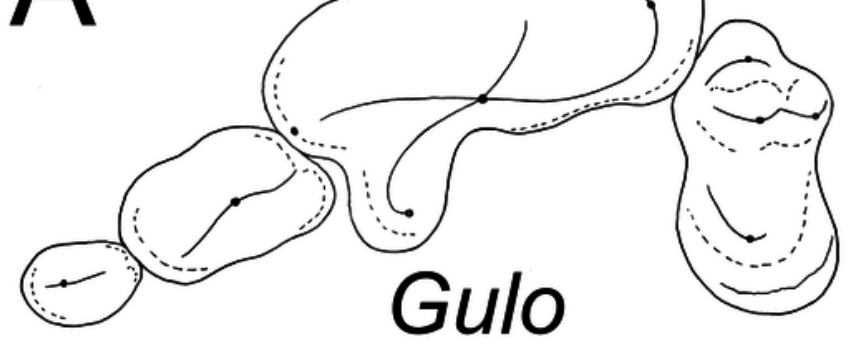

C

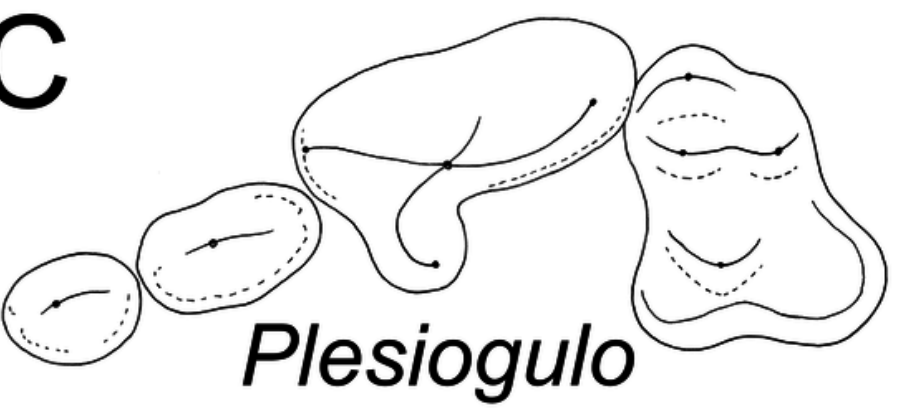

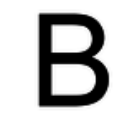
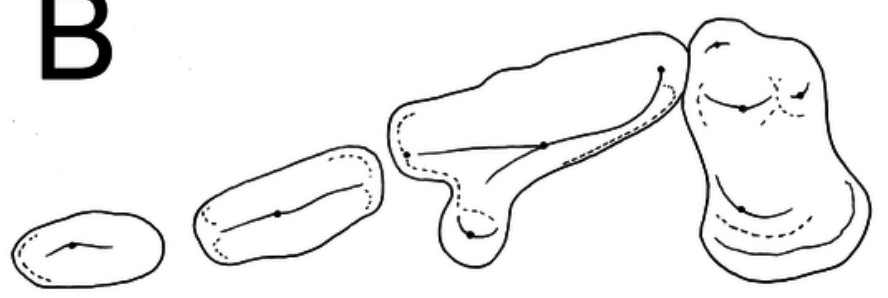

Pekania

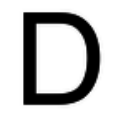

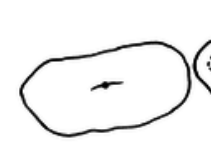

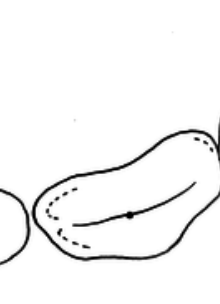

\section{Martes}




\section{Figure 5}

Phylogeny of gulonine mustelids with estimated divergence times and geologic ages of known fossils.

Phylogenetic relationships of extant taxa based on cladistics analyses of Koepfli et al., 2008; Sato et al., 2012; and Li et al., 2014. Note that the placements of extinct taxa are not based on a cladistic analysis, rather they are based morphological comparisons made in this manuscript and prior studies. Divergence times (indicated by horizontal boxes) are based on protein coding region data set in Li et al. (2014), except divergence time of Guloninae from other "crown" mustelids (Helictidinae, Ictonychinae, Lutrinae, and Mustelinae) based on multidivtime analysis of Sato et al. (2012). Age ranges of fossil taxa (thick black lines) are based on occurrences and references listed in Supplemental Table 1 and data sources listed in the Geologic Setting section. 


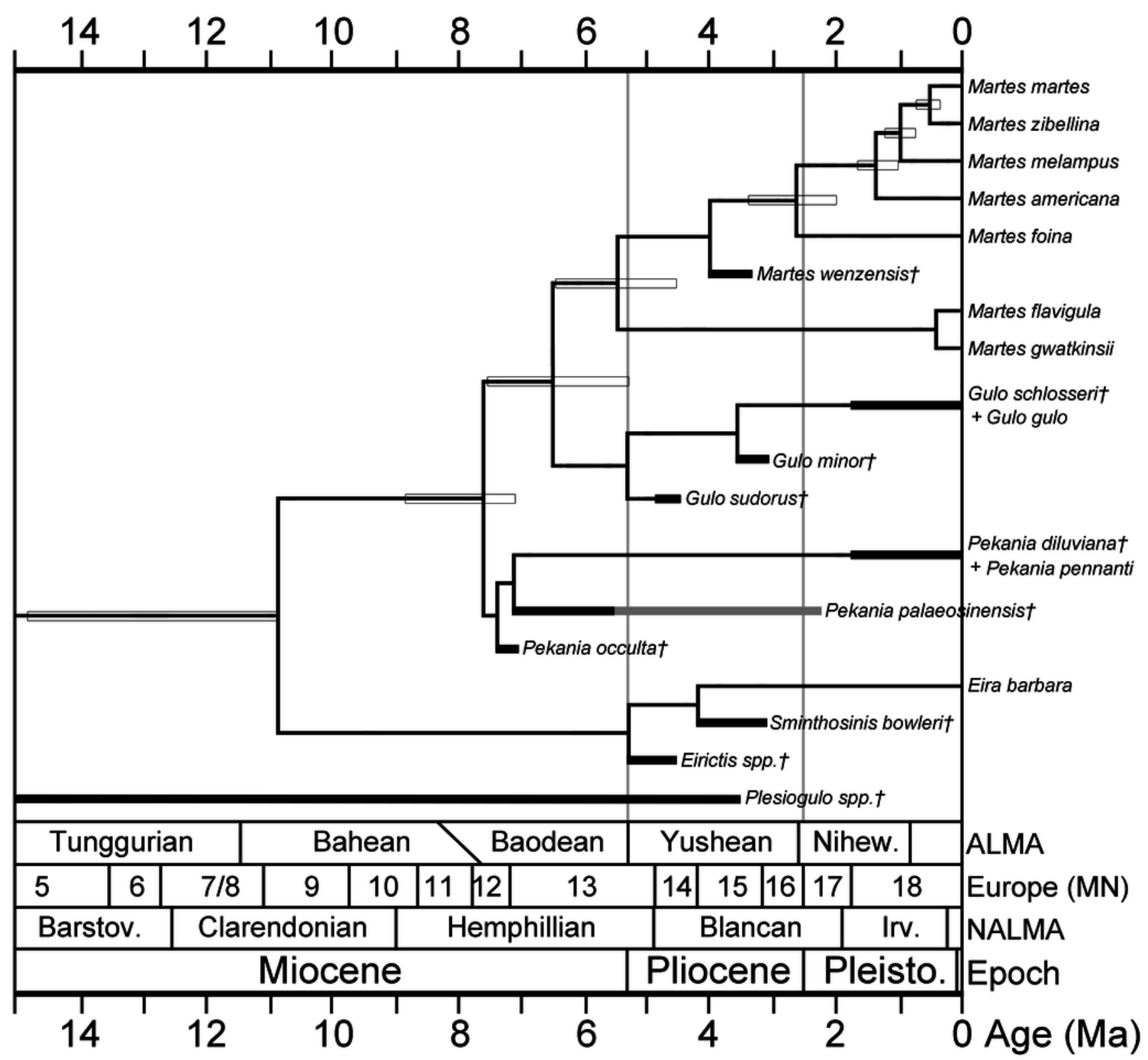




\section{Figure 6}

Gulo gulo (ETVP 269) with an atavistic external median rootlet on the upper P4, which is exposed through the lateral surface of the maxilla.

Scale bar equals $1 \mathrm{~cm}$. Photograph by Joshua Samuels.

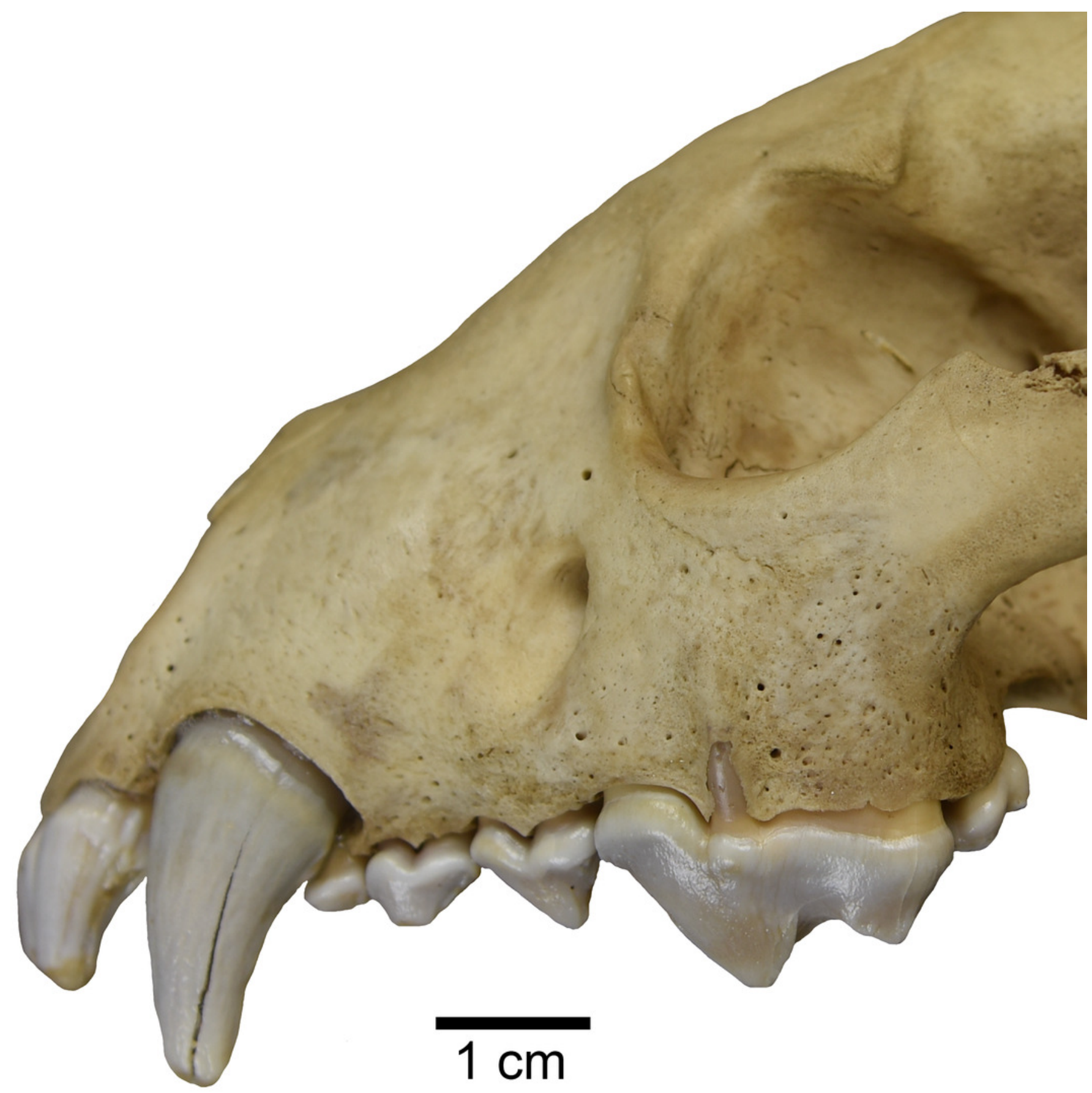




\section{Table $\mathbf{1}$ (on next page)}

Dental measurements (in $\mathrm{mm}$ ) of gulonines and some other mustelid species.

Measurements derived from literature sources include the following: Gulo gulo (Holocene) from Anderson (1998), G. gulo (Pleistocene) from Döppes (2001) and Baryshnikov (2015), G. schlosseri from Gazin \& Gidley (1938) ("Gulo gidleyi") and Bonifay (1971), Iberictis azanzae from Ginsburg \& Morales (1992), Plesiogulo brachygnathus from Zdansky (1924), P. crassa and P. praecocidens from Kurtén (1970), P. lindsayi and P. marshalli from Harrison (1981), $P$. monspessulanus from Hendey (1978), P. botori from Haile-Selassie, Hlusko, \& Howell (2004), Sminthosinis bowleri from Bjork 1970. Pekania diluviana from Gidley \& Gazin (1933), P. palaeosinensis from Zdansky (1924) and Wang, Tseng, \& Takeuchi (2012), Ischyrictis zibethoides from (Peigné 2012), Martes ginsburgi from Montoya, Morales, \& Abella (2011), and $M$. wenzensis from Stach (1959). Complete listing of measurements for individuals are included in Supplemental Table 2. 
1 Table 1. Dental measurements (in $\mathrm{mm}$ ) of gulonines and some other mustelid species. Measurements derived from literature sources

2 include the following: Gulo gulo (Holocene) from Anderson (1998), Gulo gulo (Pleistocene) from Döppes (2001) and Baryshnikov

3 (2015), Gulo schlosseri from Gazin \& Gidley (1938) (“Gulo gidleyi”) and Bonifay (1971), Iberictis azanzae from Ginsburg \&

4 Morales (1992), Plesiogulo brachygnathus from Zdansky (1924), P. crassa and P. praecocidens from Kurtén (1970), P. lindsayi and

5 P. marshalli from Harrison (1981), P. monspessulanus from Hendey (1978), P. botori from Haile-Selassie, Hlusko, \& Howell (2004),

6 Sminthosinis bowleri from Bjork 1970. Pekania diluviana from Gidley \& Gazin (1933), P. palaeosinensis from Zdansky (1924) and

7 Wang, Tseng, \& Takeuchi (2012), Ischyrictis zibethoides from (Peigné 2012), Martes ginsburgi from Montoya, Morales, \& Abella

8 (2011), and M. wenzensis from Stach (1959). Complete listing of measurements for individuals are included in Supplemental Table 2.

\begin{tabular}{|c|c|c|c|c|c|c|c|c|c|c|c|c|c|c|}
\hline Species & Specimen No. & Locality & P2L & P2W & P4L & P4W $W_{\text {pro }}$ & P4W $W_{\text {met }}$ & M1L $_{\text {ext }}$ & M1L $_{\text {int }}$ & M1W & $\begin{array}{l}\text { P2L/ } \\
\text { P4L }\end{array}$ & $\begin{array}{l}\text { P4W } \\
\text { /P4L }\end{array}$ & $\begin{array}{l}\text { P4W } \\
\text { /P4L }\end{array}$ & $\begin{array}{l}\text { P4L/ } \\
\text { M1L }_{\text {int }}\end{array}$ \\
\hline $\begin{array}{l}\text { Gulo sudorus } \\
\text { new species }\end{array}$ & ETMNH 3663 & $\begin{array}{l}\text { Gray Fossil } \\
\text { Site, TN }\end{array}$ & 7.93 & 6.05 & 21.23 & 13.19 & 8.09 & & & & 0.374 & 0.621 & 0.381 & \\
\hline $\begin{array}{l}\text { Gulo gulo } \\
\text { (Recent) }\end{array}$ & $\begin{array}{l}\text { Mean }(\mathrm{n}=36) \\
\text { Min. } \\
\text { Max. }\end{array}$ & Various & $\begin{array}{l}6.49 \\
5.40 \\
7.80 \\
\end{array}$ & $\begin{array}{l}4.38 \\
3.70 \\
5.29\end{array}$ & $\begin{array}{l}19.79 \\
17.70 \\
23.90\end{array}$ & $\begin{array}{l}11.49 \\
10.30 \\
14.04 \\
\end{array}$ & $\begin{array}{l}7.28 \\
6.30 \\
9.30 \\
\end{array}$ & $\begin{array}{l}7.10 \\
6.16 \\
8.12 \\
\end{array}$ & $\begin{array}{l}8.02 \\
7.29 \\
8.77 \\
\end{array}$ & $\begin{array}{l}13.89 \\
12.88 \\
14.92 \\
\end{array}$ & $\begin{array}{l}0.328 \\
0.303 \\
0.402 \\
\end{array}$ & $\begin{array}{l}0.581 \\
0.518 \\
0.619\end{array}$ & $\begin{array}{l}0.385 \\
0.359 \\
0.409\end{array}$ & $\begin{array}{l}2.646 \\
2.511 \\
2.769 \\
\end{array}$ \\
\hline $\begin{array}{l}\text { Gulo gulo } \\
\text { (Holocene) }\end{array}$ & $\begin{array}{l}\text { Min. }(n=5) \\
\text { Max. } \\
\text { Min. }(n=14) \\
\text { Max. }\end{array}$ & $\begin{array}{l}\text { Middle Butte } \\
\text { Cave, ID } \\
\text { Moonshiner } \\
\text { Cave, ID }\end{array}$ & $\begin{array}{l}6.9 \\
5.7 \\
5.8 \\
7.0\end{array}$ & $\begin{array}{l}3.9 \\
4.7 \\
3.6 \\
5.0\end{array}$ & $\begin{array}{l}18.0 \\
21.5 \\
18.0 \\
22.2\end{array}$ & $\begin{array}{l}9.6 \\
12.1 \\
9.4 \\
12.9\end{array}$ & & & $\begin{array}{l}7 \\
8.1 \\
6.6 \\
8.7\end{array}$ & $\begin{array}{l}11.8 \\
13.8 \\
11.9 \\
14.2\end{array}$ & $\begin{array}{l}0.317 \\
0.321 \\
0.315 \\
0.322\end{array}$ & $\begin{array}{l}0.522 \\
0.581 \\
0.533 \\
0.563\end{array}$ & & $\begin{array}{l}2.552 \\
2.727 \\
2.571 \\
2.654\end{array}$ \\
\hline $\begin{array}{l}\text { Gulo gulo } \\
\text { (Pleistocene - } \\
\text { Eurasia) }\end{array}$ & $\begin{array}{l}\text { Mean }(\mathrm{n}=18) \\
\text { Min. } \\
\text { Max. }\end{array}$ & Various & $\begin{array}{l}7.17 \\
6.6 \\
7.9 \\
\end{array}$ & $\begin{array}{l}4.82 \\
4.3 \\
5.5 \\
\end{array}$ & $\begin{array}{l}22.02 \\
19.7 \\
23.2 \\
\end{array}$ & $\begin{array}{l}12.96 \\
11.5 \\
14.4 \\
\end{array}$ & & & & & $\begin{array}{l}0.324 \\
0.301 \\
0.364 \\
\end{array}$ & $\begin{array}{l}0.590 \\
0.550 \\
0.619 \\
\end{array}$ & & \\
\hline $\begin{array}{l}\text { Gulo schlosseri } \\
\text { (Pleistocene - } \\
\text { North America) }\end{array}$ & $\begin{array}{l}\text { USNM V8175 } \\
\text { USNM V8176 }\end{array}$ & $\begin{array}{l}\text { Cumberland } \\
\text { Cave, MD }\end{array}$ & 7.38 & 4.9 & $\begin{array}{l}18.9 \\
21.84\end{array}$ & $\begin{array}{l}11 \\
11.65\end{array}$ & $\begin{array}{l}7.3 \\
8.5\end{array}$ & 6.98 & 9.18 & 14.46 & 0.338 & $\begin{array}{l}0.582 \\
0.533\end{array}$ & $\begin{array}{l}0.386 \\
0.389\end{array}$ & 2.379 \\
\hline Pekania occulta ${ }^{\dagger}$ & JODA 15214 & $\begin{array}{l}\text { Rattlesnake } \\
\text { Fm., OR }\end{array}$ & & 3.0 & 13.25 & 8.78 & 5.31 & 5.56 & 8.54 & 12.84 & & 0.663 & 0.401 & 1.552 \\
\hline $\begin{array}{l}\text { Pekania } \\
\text { palaeosinensis }\end{array}$ & IVPP V 18408 & $\begin{array}{l}\text { Baogeda Ula, } \\
\text { China }\end{array}$ & 5.8 & 2.19 & 12.38 & 6.29 & 3.95 & & & & 0.468 & 0.508 & 0.319 & \\
\hline
\end{tabular}




\begin{tabular}{|c|c|c|c|c|c|c|c|c|c|c|c|c|c|c|}
\hline & $\begin{array}{l}\text { Mean }(n=7) \\
\text { Min. } \\
\text { Max. }\end{array}$ & Baode, China & $\begin{array}{l}5.12 \\
4.2 \\
5.7 \\
\end{array}$ & $\begin{array}{l}2.32 \\
1.9 \\
2.5 \\
\end{array}$ & $\begin{array}{l}10.54 \\
9.0 \\
11.5 \\
\end{array}$ & $\begin{array}{l}6.07 \\
4.6 \\
6.7 \\
\end{array}$ & 4 & 5.7 & 6.5 & 10.4 & $\begin{array}{l}0.486 \\
0.467 \\
0.496 \\
\end{array}$ & $\begin{array}{l}0.576 \\
0.511 \\
0.583 \\
\end{array}$ & 0.364 & 1.692 \\
\hline $\begin{array}{l}\text { Pekania } \\
\text { diluviana }\end{array}$ & USNM V8010 & $\begin{array}{l}\text { Cumberland } \\
\text { Cave, MD }\end{array}$ & & & 10.2 & 6 & 3.9 & 5 & 6 & 9.5 & & 0.588 & 0.382 & 1.7 \\
\hline $\begin{array}{l}\text { Pekania } \\
\text { pennanti }\end{array}$ & $\begin{array}{l}\text { Mean }(\mathrm{n}=22) \\
\text { Min. } \\
\text { Max. }\end{array}$ & Various & $\begin{array}{l}5.45 \\
4.66 \\
6.42 \\
\end{array}$ & $\begin{array}{l}2.79 \\
2.04 \\
3.18 \\
\end{array}$ & \begin{tabular}{|l|}
11.54 \\
9.98 \\
13.36 \\
\end{tabular} & $\begin{array}{l}6.98 \\
5.83 \\
7.88 \\
\end{array}$ & $\begin{array}{l}4.22 \\
3.34 \\
4.91 \\
\end{array}$ & $\begin{array}{l}5.78 \\
4.87 \\
6.52 \\
\end{array}$ & $\begin{array}{l}6.86 \\
5.47 \\
7.77 \\
\end{array}$ & $\begin{array}{l}10.09 \\
8.43 \\
11.51 \\
\end{array}$ & $\begin{array}{l}0.472 \\
0.423 \\
0.513 \\
\end{array}$ & $\begin{array}{l}0.605 \\
0.575 \\
0.650 \\
\end{array}$ & $\begin{array}{l}0.364 \\
0.335 \\
0.403 \\
\end{array}$ & $\begin{array}{l}1.695 \\
1.521 \\
1.969 \\
\end{array}$ \\
\hline $\begin{array}{l}\text { Martes } \\
\text { ginsburgi }{ }^{+}\end{array}$ & VV-11759 & $\begin{array}{l}\text { Venta del } \\
\text { Moro, Spain }\end{array}$ & & & 8.9 & 5.7 & & 5.4 & 8.3 & & & 0.640 & & 1.648 \\
\hline $\begin{array}{l}\text { Martes } \\
\text { wenzensist }\end{array}$ & Holotype & Węże 1, Poland & 5.8 & 3.0 & 12.0 & & 5.2 & & 6.6 & 10.5 & 0.483 & & 0.433 & 1.818 \\
\hline $\begin{array}{l}\text { Martes } \\
\text { americana }\end{array}$ & $\begin{array}{l}\text { Mean }(\mathrm{n}=11) \\
\text { Min. } \\
\text { Max. }\end{array}$ & Various & $\begin{array}{l}4.33 \\
3.21 \\
5.15 \\
\end{array}$ & $\begin{array}{l}2.00 \\
1.57 \\
2.23 \\
\end{array}$ & $\begin{array}{l}7.80 \\
6.50 \\
9.17 \\
\end{array}$ & $\begin{array}{l}4.86 \\
3.90 \\
5.80 \\
\end{array}$ & $\begin{array}{l}2.84 \\
1.90 \\
3.51 \\
\end{array}$ & $\begin{array}{l}3.79 \\
3.09 \\
4.68 \\
\end{array}$ & $\begin{array}{l}5.23 \\
3.78 \\
6.64 \\
\end{array}$ & $\begin{array}{l}7.88 \\
6.01 \\
9.36 \\
\end{array}$ & $\begin{array}{l}0.557 \\
0.473 \\
0.625 \\
\end{array}$ & $\begin{array}{l}0.622 \\
0.582 \\
0.642 \\
\end{array}$ & $\begin{array}{l}0.362 \\
0.292 \\
0.396 \\
\end{array}$ & $\begin{array}{l}1.536 \\
1.334 \\
1.728 \\
\end{array}$ \\
\hline M. martes & LACM 74508 & & 5.34 & 2.78 & 9.25 & 6.12 & 3.36 & 4.72 & 7.81 & 9.55 & 0.577 & 0.662 & 0.363 & 1.184 \\
\hline M. flavigula & LACM 8229 & & 5.22 & 2.6 & 10.11 & 6.42 & 3.48 & 4.02 & 5.31 & 9.57 & 0.516 & 0.635 & 0.344 & 1.904 \\
\hline M. foina & ETVP 5535 & & 4.1 & 2.43 & 9.37 & 5.83 & 3.36 & 5.2 & 5.55 & 9.22 & 0.438 & 0.622 & 0.359 & 1.688 \\
\hline Eira barbara & $\begin{array}{l}\text { Mean }(n=5) \\
\text { Min. } \\
\text { Max. }\end{array}$ & Various & $\begin{array}{l}3.85 \\
3.30 \\
4.31 \\
\end{array}$ & $\begin{array}{l}2.84 \\
2.56 \\
3.04 \\
\end{array}$ & $\begin{array}{l}10.06 \\
9.23 \\
10.62 \\
\end{array}$ & $\begin{array}{l}6.90 \\
6.47 \\
7.49 \\
\end{array}$ & $\begin{array}{l}3.66 \\
3.58 \\
3.85 \\
\end{array}$ & $\begin{array}{l}3.60 \\
2.65 \\
4.25 \\
\end{array}$ & $\begin{array}{l}4.68 \\
3.61 \\
5.57 \\
\end{array}$ & $\begin{array}{l}8.73 \\
8.17 \\
9.52 \\
\end{array}$ & $\begin{array}{l}0.382 \\
0.347 \\
0.406 \\
\end{array}$ & $\begin{array}{l}0.687 \\
0.610 \\
0.743 \\
\end{array}$ & $\begin{array}{l}0.365 \\
0.337 \\
0.417 \\
\end{array}$ & $\begin{array}{l}2.183 \\
1.905 \\
2.637 \\
\end{array}$ \\
\hline $\begin{array}{l}\text { Sminthosinis } \\
\text { bowlerit }\end{array}$ & $\begin{array}{l}\text { UMMP } 52868 \\
\text { UMMP } 55214 \\
\end{array}$ & Hagerman, ID & $\begin{array}{l}5.38 \\
4.98 \\
\end{array}$ & 2.15 & $\begin{array}{l}9.6 \\
9.65 \\
\end{array}$ & $\begin{array}{l}5.35 \\
5 \\
\end{array}$ & & & 4.76 & 7.47 & $\begin{array}{l}0.560 \\
0.516 \\
\end{array}$ & $\begin{array}{l}0.557 \\
0.518 \\
\end{array}$ & & 2.017 \\
\hline $\begin{array}{l}\text { Ischyrictis } \\
\text { zibethoides }\end{array}$ & $\begin{array}{l}\text { Mean }(n=4) \\
\text { Min. } \\
\text { Max. }\end{array}$ & $\begin{array}{l}\text { Various, } \\
\text { Europe }\end{array}$ & 8.5 & 4.6 & $\begin{array}{l}15.95 \\
14.0 \\
17.8 \\
\end{array}$ & $\begin{array}{l}10.1 \\
7.9 \\
12 \\
\end{array}$ & $\begin{array}{l}5.6 \\
4.6 \\
6.6 \\
\end{array}$ & $\begin{array}{l}7.03 \\
6.65 \\
7.4 \\
\end{array}$ & $\begin{array}{l}8.58 \\
6.85 \\
9.9 \\
\end{array}$ & $\begin{array}{l}15.25 \\
13.75 \\
16.5 \\
\end{array}$ & 0.478 & $\begin{array}{l}0.630 \\
0.564 \\
0.674 \\
\end{array}$ & $\begin{array}{l}0.329 \\
0.4 \\
\end{array}$ & $\begin{array}{l}1.964 \\
1.798 \\
2.263 \\
\end{array}$ \\
\hline $\begin{array}{l}\text { Plesiogulo } \\
\text { brachygnathus }\end{array}$ & $\begin{array}{l}\text { Mean }(\mathrm{n}=10) \\
\text { Min. } \\
\text { Max. }\end{array}$ & Shansi, China & $\begin{array}{l}8.15 \\
7.6 \\
8.9 \\
\end{array}$ & $\begin{array}{l}5.85 \\
5.0 \\
6.7 \\
\end{array}$ & \begin{tabular}{l|}
19.24 \\
17.1 \\
20.5 \\
\end{tabular} & $\begin{array}{l}12.87 \\
11.1 \\
14.0 \\
\end{array}$ & & $\begin{array}{l}9.65 \\
8.4 \\
11.7 \\
\end{array}$ & $\begin{array}{l}13.54 \\
12 \\
16.3 \\
\end{array}$ & $\begin{array}{l}16.88 \\
13.8 \\
18.4 \\
\end{array}$ & $\begin{array}{l}0.420 \\
0.393 \\
0.445 \\
\end{array}$ & $\begin{array}{l}0.669 \\
0.649 \\
0.683 \\
\end{array}$ & & $\begin{array}{l}1.428 \\
1.258 \\
1.583 \\
\end{array}$ \\
\hline $\begin{array}{l}\text { Plesiogulo } \\
\text { crassa }\end{array}$ & $\begin{array}{l}\text { Mean } \\
\text { Min. } \\
\text { Max. }\end{array}$ & Paote, China & $\begin{array}{l}8.15 \\
7.8 \\
8.3 \\
\end{array}$ & 5.9 & $\begin{array}{l}19.48 \\
18.3 \\
20.8 \\
\end{array}$ & $\begin{array}{l}12.92 \\
12.3 \\
14.2 \\
\end{array}$ & & $\begin{array}{l}8.4 \\
7.6 \\
9 \\
\end{array}$ & $\begin{array}{l}13.22 \\
11.9 \\
14.8 \\
\end{array}$ & $\begin{array}{l}16.98 \\
15.8 \\
17.8 \\
\end{array}$ & 0.418 & 0.663 & & 1.473 \\
\hline $\begin{array}{l}\text { Plesiogulo } \\
\text { minor }^{+}\end{array}$ & Holotype & $\begin{array}{l}\text { K'ingyang, } \\
\text { China }\end{array}$ & & & 17 & 10.5 & & 7.9 & 11.2 & 14.3 & & 0.618 & & 1.518 \\
\hline $\begin{array}{l}\text { Plesiogulo } \\
\text { praecocidens }{ }^{\dagger}\end{array}$ & $\begin{array}{l}\text { UPI No. M19 } \\
(5)\end{array}$ & Paote, China & & & 17.2 & 10.9 & & 7.8 & 12.4 & 13.8 & & 0.634 & & 1.387 \\
\hline $\begin{array}{l}\text { Plesiogulo } \\
\text { lindsayi }{ }^{+}\end{array}$ & $\mathrm{F}: \mathrm{AM} 49384$ & $\begin{array}{l}\text { Wikieup, } \\
\text { Arizona }\end{array}$ & 9.5 & 6.9 & 23.5 & 17.3 & & 9.7 & 14.6 & 20.6 & 0.404 & 0.736 & & 1.610 \\
\hline Plesiogulo & Mean $(n=8)$ & Various, North & 8.01 & 5.83 & 19.75 & 13.25 & 8.59 & 9.88 & 13.95 & 17.58 & 0.416 & 0.670 & 0.434 & 1.411 \\
\hline
\end{tabular}




\begin{tabular}{|l|l|l|l|l|l|l|l|l|l|l|l|l|l|}
\hline marshalli $^{\dagger}$ & $\begin{array}{l}\text { Min. } \\
\text { Max. }\end{array}$ & America & $\begin{array}{l}7.84 \\
8.2\end{array}$ & $\begin{array}{l}5.7 \\
5.9\end{array}$ & $\begin{array}{l}18.2 \\
22.04\end{array}$ & $\begin{array}{l}12.1 \\
15.0\end{array}$ & $\begin{array}{l}7.81 \\
9.80\end{array}$ & $\begin{array}{l}8.3 \\
11.87\end{array}$ & $\begin{array}{l}12.45 \\
15.9\end{array}$ & $\begin{array}{l}17.0 \\
18.5\end{array}$ & $\begin{array}{l}0.640 \\
0.696\end{array}$ & $\begin{array}{l}0.422 \\
0.445\end{array}$ & $\begin{array}{l}1.238 \\
1.749\end{array}$ \\
\hline $\begin{array}{l}\text { Plesiogulo } \\
\text { monspessulanus }\end{array}$ & L40042 & $\begin{array}{l}\text { Langebaanweg, } \\
\text { South Africa }\end{array}$ & 9.7 & 7.2 & 23.2 & 15.6 & & & 15.4 & 18.6 & 0.418 & 0.672 & \\
\hline $\begin{array}{l}\text { Plesiogulo } \\
\text { botori }^{\dagger}\end{array}$ & $\begin{array}{l}\text { KNM-NK } \\
41420\end{array}$ & Narok, Kenya & & & 24.5 & 16.7 & & 10.1 & 15.9 & 21.2 & 1.506 \\
\hline $\begin{array}{l}\text { Iberictis } \\
\text { azanzae }^{\dagger}\end{array}$ & Holotype & Artesilla, Spain & & & 15.5 & $? 9.7$ & & & 10.9 & $? 16$ & & 0.682 & \\
\hline
\end{tabular}

9 